\title{
Research and Development of Macrocyclic Compounds as Fungicides
}

\author{
Dao-Quan Wang \\ Department of Applied Chemistry, China Agricultural University, Beijing, \\ People' Republic of China
}

\section{Introduction}

"The latest economical development in agriculture calls for an increasing demand for food and feed on optimized plant production. If we are to intensify crop production, the efficient control of plant disease is essential. At present the most reliable means of doing this is by the use of fungicides" (Dehne, 2007). Unfortunately, resistance to these fungicides has always been observed, thus, leading to the continuing need of further research to discover new classes of fungicides, especially those with novel modes of action. One strategy for discovering new fungicides is to mimick the chemistry of biologically active natural products. Naturally occurring macrocyclic compounds, especially macrolactam and macrolactone have attracted considerable interest of chemists and the natural products community because they display a diverse range of biological activity including pesticidal activity. Several examples include avermectins, a group of 16-membered ring lactones with anthelmintic, insecticidal and acaricidal activities (Fisher, 1990 and Green, 1991), spinosyns, a group of 12-membered ring lactones with insecticidal activity (Sparks et al, 1998; Crouse et al, 2001), epilachnene, a kind of structurally novel azamacrolide with antifeedant activity (Attygalle et al, 1993), pyrenophorol, a macrodiolide with herbicidal activity (Kastanise and Chrysayi-Tokousbalides, 2000), and maltophilin, a novel macrolactam, produced by strains of Stenotrophomonas maltophilia R3089 isolated from the rhizosphere of rape plants (Brassica napus L.), which exhibited biological activity against a broad spectrum of fungi (Jakobi et al, 1996).

This chapter will describe the discovery of fungicidal novel lead compounds, especially those macrocyclic compounds which have relative simple structure and can be synthesized easily from readily available raw materials, by mimicking the structure of natural occurring macrolactone and macrolactam, and the development of the compounds with high fungicidal activity.

\section{Research of the cyclododecanone derivatives}

Cyclododecanone is an important intermediate in the organic synthesis and can be prepared from cyclododecatriene which can easily be produced in the large scale from petrochemical product butadiene (Wilke \& Muller, 1958 and Weber et al, 1965). In this section, synthesis and fungicidal activity of several series of cyclododecanone derivatives are described. 


\subsection{Synthesis and fungicidal activity of 2-oxocyclododecylsulfonamides (3) and 2- oxocyclododecylsulfonylureas (5)}

Wang and Wang (1997) reported the synthesis and fungicidal activity of 2oxocyclododecylsulfonamides (3). Compounds 3 were synthesized by amination of 2oxocyclododecylsulfonic acid chloride, obtained from the readily available cyclododecanone (1) via 2-oxocyclododecylsulfonate (Scheme 1).

Bioassay showed that compounds 3 are active against G. zeae (Gibberella zeae Petch). Among them, compounds only having one substituent on the nitrogen of sulfonic acid amide group are more active than those having two substituents on the nitrogen of sulfonic acid amide group. This may mean the importance of hydrogen-bonding donor in the structure. In addition, QSAR study (CoMFA) (Xie et al, 1999) showed that 2oxocyclododecylsulfonylureas (5) may have higher predicted fungicidal activity although some types of sulfonylureas are high efficient chemical herbicides. Thus, a series of compounds 5 were synthesized (Li et al, 2005) (Scheme 2).

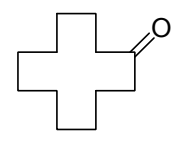

1

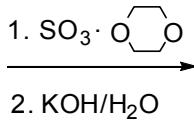

2. $\mathrm{KOH} / \mathrm{H}_{2} \mathrm{O}$

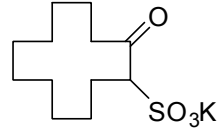

2

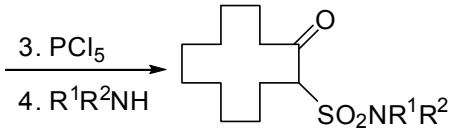

3

Scheme 1. Synthetic route of 2-oxocyclododecylsulfonamides (3)
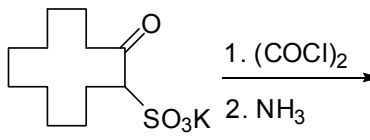

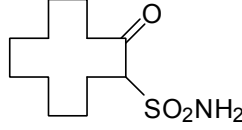

4

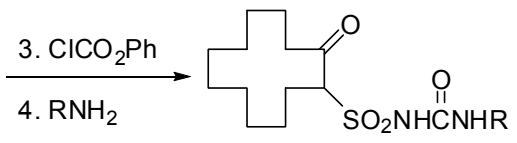

5

Scheme 2. Synthetic route of 2-oxocyclododecylsulfonylureas (5)

Compound 2 was allowed to react with oxalyl chloride to give corresponding sulfonyl chloride, which was converted into sulfonamide (4) using $\mathrm{NH}_{3}$. The reaction of 4 with phenyl chloroformate and amines successively afforded desired compounds $\mathbf{5}$. Bioassay showed that compounds 5 exhibited some fungicidal activity against G. zeae but do not fully accord with the prediction of CoMFA. The fungicidal activity of a representative compounds, $\mathrm{N}$-(2,5-dichlorophenyl)-N'-(2-oxocyclododecylsulfonyl)urea against seven fungi [ (G. zeae, B. cinerea (Botrytis cinerea Pers), C. orbiculare (Colletotrichum orbiculare Arx), P. aphanidermatum (Pythium aphanidermatum Fitzp), F. oxysporum (Fusarium oxysporum Schl.f.sp Vasinfectum), R. solani (Rhizoctonia solani Kuhn), and V. dahliae (Verticillium dahliae Kled) ] was further evaluated. The results showed that it has better fungicidal activity against $C$. orbiculare and $P$. aphanidermatum than the commercial fungicide carbendazim. In addition, corresponding 2-oxocyclohexylsulfonylureas (6) and 2-oxocycloheptylsulfonylureas (7) were also synthesized and their fungicidal activity against G. zeae was evaluated. The result showed that compounds containing 12-membered ring (5) are more active than those containing 6- or 7-membered ring $(6,7)$, which indicated that 2-oxocyclododecyl may be an active group showing pesticidal activity and is worth to pay attention to in research and development of novel pesticides. 
<smiles>NC(=O)NOS(=O)(=O)[O-]</smiles>

6<smiles>[R]NC(=O)NOS(=O)(=O)C1CCCCCC1=O</smiles>

7

\subsection{Synthesis and fungicidal activity of $(E)$ - $\alpha$-oxocyclododecanone oxime ethers (9)} Li et al (2006) reported the synthesis and fungicidal activity of $(E)$-a-oxocyclododecanone oxime ethers (9). As shown in Scheme 3, compounds 9 were synthesized by oximation of cyclododecanone followed by etherification. Configuration of a-oxocyclododecanone oxime (8) was determined to be $E$ isomer via the Beckmann reaction which gives 11cyanoundodecanoic acid (Hou et al, 1999). Its $E$ configuration was further confirmed by single crystal X-ray diffraction analysis of a representative of compound $9\left(\mathrm{R}=4-\mathrm{FC}_{6} \mathrm{H}_{4} \mathrm{CH}_{2}\right)$ (Li et al, 2006).

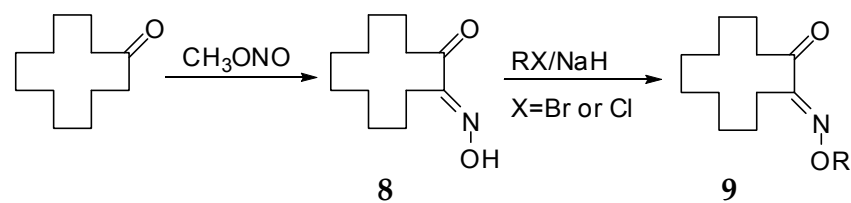

Scheme 3. Synthetic route of (E)-a-oxocyclododecanone oxime ethers (9)

Bioassay showed that most of compounds 9 present good fungicidal activity against $R$. solani, C. cucumerinum (Cladosporium cucumerinum Ell.et Arthur), C. orbiculare, B. cinerea, F. oxysporum, and P. asparagi (Phomopsis asparagi Bubak). Although their activity against $R$. solani, C. cucumerinum, B. cinerea, F. oxysporum and P. asparagi are lower than commercial fungicides carbendazim, but the activity of individual compound (e.g. $\mathrm{R}=\mathrm{CH}_{2} \mathrm{CO}_{2} \mathrm{CH}_{3}$ ) against $C$. orbiculare is better than carbendazim.

\subsection{Synthesis and fungicidal activity of 2-(1,11-undecylidene)-5-substituted imino- $\Delta^{3}$ -} 1,3,4-thiadiazolines (11)

Zhang et al (2001) and Chen et al (2002) reported the synthesis and fungicidal activity of 2(1,11-undecylidene)-5-substituted imino- $\Delta^{3}-1,3,4$-thiadiazolines (11).

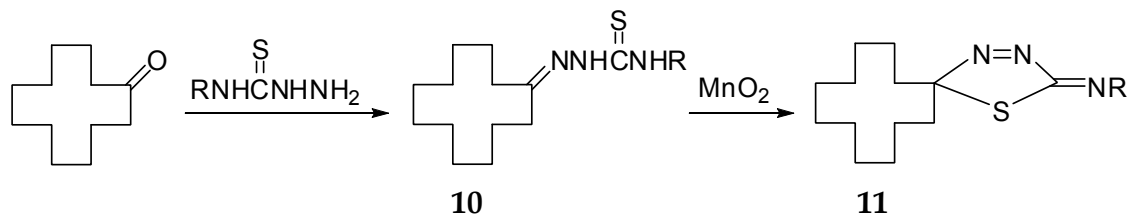

Scheme 4. Synthetic route of 2-(1,11-undecylidene)-5-substituted imino- $\Delta^{3}-1,3,4-$ thiadiazolines (11)

As shown in Scheme 4, Compounds 11 were synthesized by oxidative cyclisation of Nsubstituted cyclododecanone thiosemicarbazones (10), prepared by condensation reaction of cyclododecanone and $\mathrm{N}$-substituted thiosemicarbazide, on treatment with manganese dioxide. The conformation of compounds $\mathbf{1 1}$ was analyzed by NMR, molecular mechanic calculation and X-ray diffraction study (Wang et al, 2002). Bioassay showed that most of 
compounds $\mathbf{1 1}$ have some fungicidal activity against $R$. solani and $V$. dahlide and individual compound exhibit good activity against $R$. solani.

Synthesis and fungicidal activity of $\alpha$-methylthiocyclododecanone oxime ethers (14) Song et al (2005) reported the synthesis and fungicidal activity of amethylthiocyclododecanone oxime ethers (14). As shown in Scheme 5, compounds 14 were synthesized by alkylation of a-methylthiocyclododecanone oxime, which was prepared by methylthiolation of cyclododecanone followed by oximation.

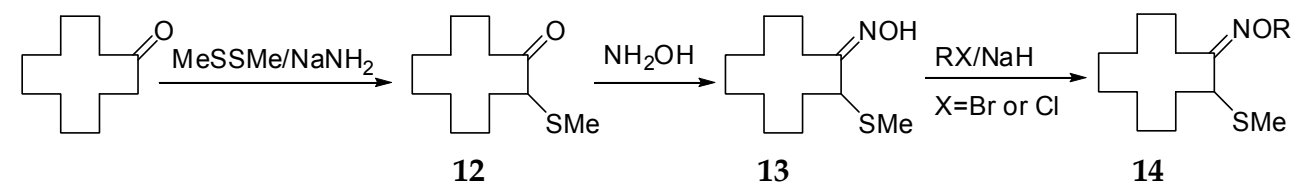

Scheme 5. Synthetic route of a-methylthiocyclododecanone oxime ethers (14)

Bioassay showed that some of compounds $\mathbf{1 4}$ have good fungicidal activity against $R$. solani and B. cinerea.

Apart from mentioned above compounds (compounds 3, 5, 9, 11 and 14) carrying two substituents on the cyclododecane ring (carbonyl group and side chain, and thiadiazoline ring of compounds $\mathbf{1 1}$ may be considered as two substituents on the spiro carbon atom), monosubstituted cyclododecane derivatives, for example, 15, 16 and 17, were synthesized and were found to be completely ineffective as fungicides (Huang et al, 2007) (Figure 1). It is suggested that the coexistence of two polarizable groups on the cyclododecane ring is necessary for fungicidal activity of the cyclododecanone class of compounds. The results showed that it should be very useful for designing new classes of macrocyclic fungicides, especially those with novel modes of action.

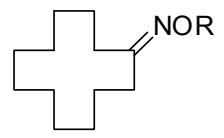

15

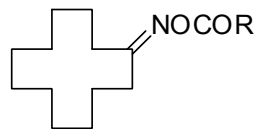

16

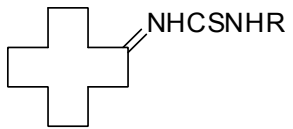

17

Fig. 1. Chemical structure of several monosubstituted cyclododecane derivatives

\section{Research of macrolactam and macrolactone derivatives}

In this section, the improvement of the fungicidal activity of the compounds with higher fungicidal activity (compounds 3, 9 and 11) in section 1 through structural derivation was described. The approach is to replace the cyclododecane ring in the cyclododecanone derivatives by macrolactam or macrolactone rings.

\subsection{Synthesis and fungicidal activity of macrolactams and macrolactones with an oxime ether side chain $(23,30$ and 34$)$}

The improvement of the fungicidal activity of compounds 9 through the replacement of cyclododecane ring by macrolactam or macrolactone rings was described (Huang et al, 2007). Compounds 12-alkoxyiminotetradecanlactam (23), 12-alkoxyiminopentadecanlactam (30) and 12-alkoxyiminopentadecanlactone (34) were designed. 


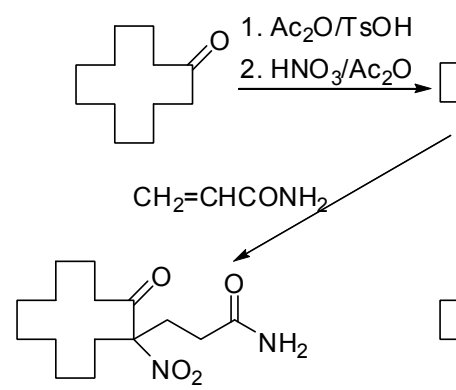

19

1. $\mathrm{Pb}(\mathrm{OAc})_{4}$

2. $\mathrm{CF}_{3} \mathrm{CO}_{2} \mathrm{H}$

(Hofmann rearrangement)<smiles>O=C([O-])NCCC(CCCCCCCCCCCC(=O)N[O+])[N+](=O)[O-]</smiles>

20

1. $\mathrm{CH}_{3} \mathrm{ONa} / \mathrm{CH}_{3} \mathrm{OH}$

2. $\mathrm{HCl} / \mathrm{H}_{2} \mathrm{O}$

(Nef reaction)<smiles>O=C1CCCCCCCCCC(=O)C1</smiles>

21

$\downarrow \mathrm{H}_{2} \mathrm{NOH}$

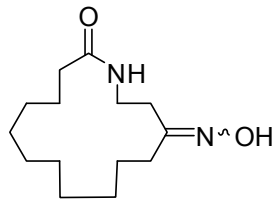

22

$\mathrm{RX} / \mathrm{NaH}$

$(\mathrm{X}=\mathrm{Cl}$ or $\mathrm{Br})$

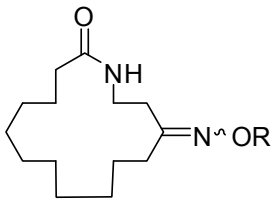

23

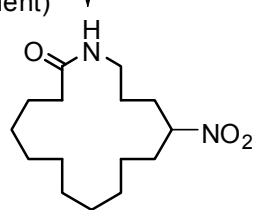

27

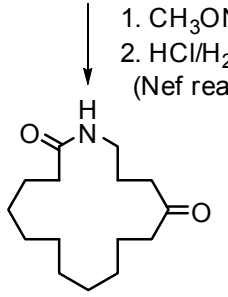

28

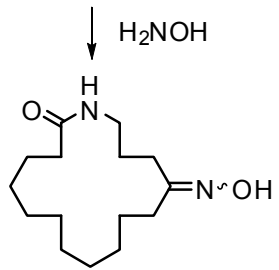

29

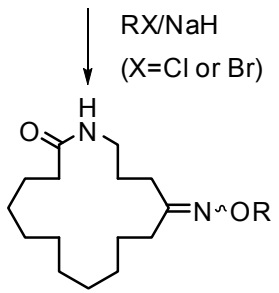

30<smiles>C=CC=CCCCCCCC(=O)C(CCCC=O)(CCCCCC=O)[N+](=O)[O-]</smiles>

24

$\mathrm{NaBH}_{4}$

1. $\mathrm{MeSO}_{2} \mathrm{Cl}$

2. $\mathrm{NaN}_{3}$

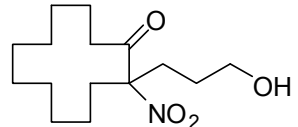

25

$\mathrm{NaH}$

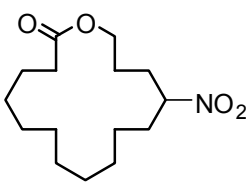

31

1. $\mathrm{CH}_{3} \mathrm{ONa} / \mathrm{CH}_{3} \mathrm{OH}$

2. $\mathrm{HCl} / \mathrm{H}_{2} \mathrm{O}$

$\checkmark$ (Nef reaction)

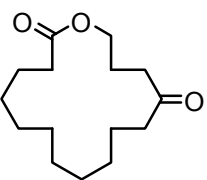

32

$\mathrm{H}_{2} \mathrm{NOH}$

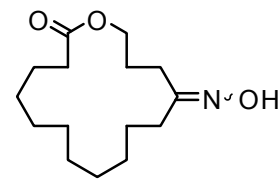

33

$\mathrm{RX} / \mathrm{NaH}$

$\checkmark(\mathrm{X}=\mathrm{Cl}$ or $\mathrm{Br})$

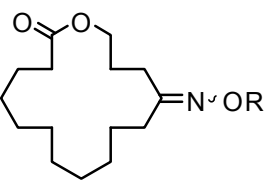

34

Scheme 6. Synthetic route of macrolactams and macrolactones with an oxime ether side chain 
Compounds 23, 30 and 34 were synthesized by oximation of compound 21, 28 and 32 followed by etherification respectively. The compound 21 was synthesized from 2nitrocyclododecanone (18), prepared from cyclododecanone, via Michael addition to acrylamide followed by Hofmann rearrangement, ring enlargement and Nef reaction (Pan and Wang, 1993; Jia et al, 2007). Compound 28 was synthesized from compound 18 via Michael addition to acrolein, selective reduction of aldehyde group followed by the conversion of hydroxyl group to amino group, ring enlargement and Nef reaction (Huang et al, 2004). Compound 32 was synthesized from compound 25 by ring enlargement and Nef reaction (Zhang et al, 2003) (Scheme 6).

Compound 18 was also synthesized from cyclododecene (35) by nitrooxidation (Fang et al, 2007) (Scheme 7).

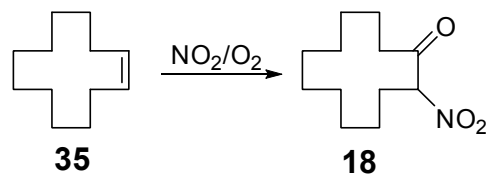

Scheme 7. Synthetic route of 2-nitrocyclododecanone (18)

Compound 27 was also synthesized from compound 18 via Michael addition to acrylnitrile followed by selective reduction of nitrile group, ring enlargement (Hou et al, 2006) (Scheme 8).

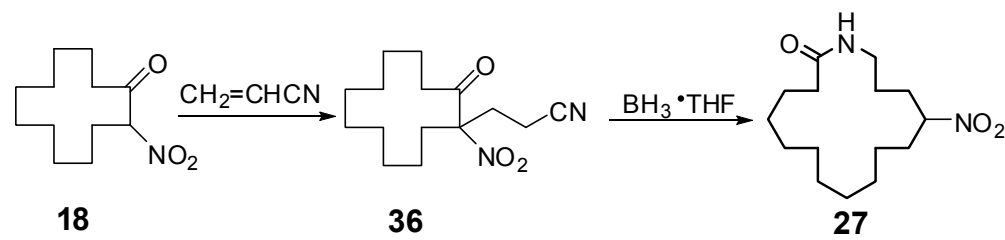

Scheme 8. Synthetic route of 12-nitro-1,15-pentadecanlactam (27)

There exist two isomers ( $Z$ and $E$ isomers) for compounds 23, 30 and 34 . The $Z$ and $E$ isomers of compounds $\mathbf{2 3}$ and $\mathbf{3 0}$ were isolated by column chromatography (Figure 2), but the two isomers of compounds 34 could not be separated due to the insufficient polarity difference in their structures.

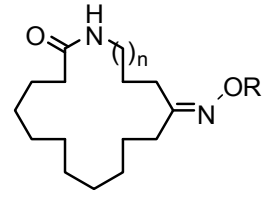

Z-isomers

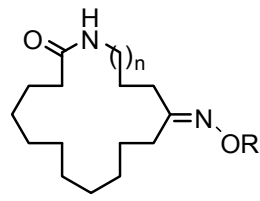

E-isomers

$\mathrm{n}=0$ for compounds $\mathbf{2 3}, \mathrm{n}=1$ for compounds 30

Fig. 2. $Z$ and $E$ isomers of compounds $\mathbf{2 3}$ and $\mathbf{3 0}$

As shown in Table 1, compounds $\mathbf{2 3}$ have fair to good fungicidal activity against $R$. solani. In general, the following structure-activity relationship in compounds $\mathbf{2 3}$ was observed: (1) The compounds with C3-C4 straight chain alkyl and benzyl without any substituent have better 
fungicidal activity; (2) $E$ isomers are more active than $Z$ isomers, especially the compounds 23a $(E), 23 \mathrm{c}(E)$, and $23 \mathrm{f}(E)$, the $\mathrm{EC}_{50}$ values of which were $9.11,7.21$ and $7.24 \mu \mathrm{g} / \mathrm{mL}$ respectively, displayed higher fungicidal activity than corresponding $Z$ isomers. The replacement of tetradecanlactam ring with pentadecanlactam ring (compounds 30) results in significantly improved fungicidal activity. For example the $\mathrm{EC}_{50}$ values of the compounds 30a $(E), 30 \mathrm{c}(E), 30 \mathrm{c}(Z)$, 30h $(Z)$ were $3.62,2.34,3.97$ and $2.34 \mu \mathrm{g} / \mathrm{mL}$ respectively. The pentadecanlactone derivatives (34) have somewhat improved fungicidal activity against $R$. solani than that of $\mathbf{2 3}$, but less active than $\mathbf{3 0}$. Namely, in the order of $\mathbf{2 3}, \mathbf{3 4}$ and $\mathbf{3 0}$, the compounds have a gradual increase of fungicidal activity. The results confirmed the original judgment in section 1: macrocyclic compounds with two polarizable groups on the ring may have certain fungicidal activity. It can also be seen from Table 1, all of tetradecanlactam and pentadecanlactam derivatives containing two polarizable groups $-\mathrm{CONH}-$ and $=\mathrm{N}-\mathrm{O}$ - on the ring (23 and 30), and pentadecanlactone derivatives containing $-\mathrm{COO}$ - and $=\mathrm{N}-\mathrm{O}$ - on the ring (34) displayed fair to excellent fungicidal activity against $R$. solani. In the macrocyclic derivatives with two polarizable groups on the ring, the compounds in which there is a three methylene distance $\left(\mathrm{CH}_{2} \mathrm{CH}_{2} \mathrm{CH}_{2}\right)$ between the two polarizable groups $(30,34)$ are more active than those in which there is a two methylene distance $\left(\mathrm{CH}_{2} \mathrm{CH}_{2}\right)$ between the two polarizable groups (23). The fact that compounds $\mathbf{3 0}$ have higher fungicidal activity than compounds $\mathbf{3 4}$ indicates that the macrocyclic derivatives with a hydrogen-bonding acceptor (here is =N-O-) and a hydrogen-bonding donor (here is - $\mathrm{CONH}-$ ) have the best fungicidal activity among the macrocyclic derivatives with two polarizable groups and a three methylenes distance between these groups.

\begin{tabular}{|c|c|c|c|c|c|c|}
\hline $\mathrm{R}$ & $\begin{array}{c}\text { Compds } \\
\text { No. }\end{array}$ & $\begin{array}{c}E_{50} \\
(\mu \mathrm{g} / \mathrm{mL})\end{array}$ & Compds No. & $\begin{array}{c}E_{50} \\
(\mu \mathrm{g} / \mathrm{mL})\end{array}$ & Compds No.* & $\begin{array}{c}E_{50} \\
(\mu \mathrm{g} / \mathrm{mL})\end{array}$ \\
\hline \multirow{2}{*}{$\mathrm{CH}_{3} \mathrm{CH}_{2} \mathrm{CH}_{2}$} & 23a $(Z)$ & 22.10 & 30a $(Z)$ & 13.14 & \multirow{2}{*}{$34 a$} & \multirow{2}{*}{8.08} \\
\hline & $23 a(E)$ & 9.11 & 30a (E) & 3.62 & & \\
\hline \multirow{2}{*}{$\mathrm{CH}_{2}=\mathrm{CHCH}_{2}$} & $23 b(Z)$ & 44.03 & $30 \mathrm{~b}(\mathrm{Z})$ & 45.61 & \multirow{2}{*}{$34 \mathrm{~b}$} & \multirow{2}{*}{12.76} \\
\hline & $23 b(E)$ & 21.76 & $30 \mathbf{b}(\mathrm{E})$ & 15.92 & & \\
\hline \multirow{2}{*}{$\mathrm{CH}_{3}\left(\mathrm{CH}_{2}\right)_{2} \mathrm{CH}_{2}$} & 23c $(Z)$ & 55.10 & 30c $(Z)$ & 3.97 & \multirow{2}{*}{$34 \mathrm{c}$} & \multirow{2}{*}{13.36} \\
\hline & $23 c(E)$ & 7.21 & 30c (E) & 2.34 & & \\
\hline \multirow{2}{*}{$\mathrm{CH}_{3}\left(\mathrm{CH}_{2}\right)_{5} \mathrm{CH}_{2}$} & 23d (Z) & 209.43 & 30d (Z) & 19.25 & \multirow{2}{*}{$34 d$} & \multirow{2}{*}{9.68} \\
\hline & 23d (E) & 50.35 & 30d (E) & 27.88 & & \\
\hline \multirow{2}{*}{$\mathrm{CH}_{3}\left(\mathrm{CH}_{2}\right)_{14} \mathrm{CH}_{2}$} & $23 \mathbf{e}(Z)$ & 135.04 & 30e $(Z)$ & 47.75 & \multirow{2}{*}{$34 \mathrm{e}$} & \multirow{2}{*}{40.39} \\
\hline & $23 e(E)$ & 127.22 & $30 \mathrm{e}(\mathrm{E})$ & 51.48 & & \\
\hline \multirow{2}{*}{$\mathrm{C}_{6} \mathrm{H}_{5} \mathrm{CH}_{2}$} & $23 f(Z)$ & 18.15 & $30 \mathrm{f}(\mathrm{Z})$ & 5.84 & \multirow{2}{*}{$34 \mathrm{f}$} & \multirow{2}{*}{45.13} \\
\hline & $23 f(E)$ & 7.24 & $30 f(E)$ & 8.28 & & \\
\hline \multirow{2}{*}{$4-\mathrm{ClC}_{6} \mathrm{H}_{4} \mathrm{CH}_{2}$} & $23 g(Z)$ & 97.25 & $30 \mathrm{~g}(\mathrm{Z})$ & 68.37 & \multirow{2}{*}{$34 \mathrm{~g}$} & \multirow{2}{*}{19.61} \\
\hline & $23 g(E)$ & 84.79 & $30 \mathrm{~g}(\mathrm{E})$ & 164.28 & & \\
\hline \multirow{2}{*}{ 2-Cl-6- $\mathrm{FC}_{6} \mathrm{H}_{3} \mathrm{CH}_{2}$} & 23h (Z) & 1734.74 & 30h (Z) & 2.34 & \multirow{2}{*}{$34 \mathrm{~h}$} & \multirow{2}{*}{51.27} \\
\hline & $23 \mathrm{~h}(\mathrm{E})$ & 42.99 & 30h (E) & 6.21 & & \\
\hline
\end{tabular}

* A mixture of $Z$ and $E$ isomers

Table 1. Fungicidal activity of compounds 23,30 and 34 against $R$. Solani 
Furthermore, compound 30a (a mixture of $Z$ and $E$ isomers) was selected as a representative to evaluated its fungicidal spectrum. The result is listed in Table 2. It can be seen from Table 2 that compound 30a has a broad spectrum of fungicidal activities, and especially has excellent fungicidal activities against A. kikuchiana (Alternaria kikuchiana), P. physaleos (Phyllospicpa physaleos Sacc), $R$. solani and B. cinerea. The EC 50 values were 1.2, 1.9, 4.6 and 8.6 $\mu \mathrm{g} / \mathrm{mL}$ respectively.

\begin{tabular}{lc}
\hline Pathogen & $\begin{array}{c}\mathrm{EC}_{50} \\
(\mu \mathrm{g} / \mathrm{mL})\end{array}$ \\
\hline Pear black spot (Alternaria kikuchiana) & 1.2 \\
Tomoto southern blight (Phyllospicpa physaleos Sacc) & 1.9 \\
Cotton rhizoctonia rot (Rhizoctonia solani Kuhn) & 4.6 \\
Cucumber grey mold (Botrytis cinerea Pers) & 8.6 \\
Asparagus stem blight (Phomopsis asparagi Sacc) & 12.0 \\
Apple ring spot (Physalospora piricola Nose) & 13.8 \\
Cotton verticillium wilt (Vercicillium alboatrum Reinke & 19.3 \\
et Berthold) & 23.9 \\
Cucumber anthracnose (Colletotrichum Lagenarium) & 29.0 \\
Cotton fusarium wilt (Fusarium vasinfectum Atkimson) & 33.3 \\
Cotton damping-off (Pythium aphanibermatum (Eds.) & 44.2 \\
Fipzp) & 53.1 \\
Tomoto early blight (Alternaria solani Jones et Grout) & 57.8 \\
Tomoto leaf mold (Cladosporium fulvum Cooke) & \\
Peppers fruit rot (Phytophthora capsici Len) & \\
\hline
\end{tabular}

Table 2. Fungicidal spectrum of 30a (a mixture of $Z$ and $E$ isomer)

\subsection{Synthesis and fungicidal activity of macrolactones and macrolactams with a sulfonamide side chain $(40,41,43$ and 47$)$}

Based on the result obtained in section 3.1 and the structural feature of compounds 3 with certain fungicidal activity, Zhu et al (2008) introduced a sulfonamide group into pentadecanlactone, designing a series of novel 12-alkylsulfonamido-1,15pentadecanlactones (40), which retain a hydrogen-bonding acceptor (here, it is -CO-O-) and a hydrogen-bonding donor (here, it is $-\mathrm{NH}_{-} \mathrm{SO}_{2-}$ ) on the large ring and still have a three methylenes distance between two polarizable groups, and expect that the compounds have a better fungicidal activity than compounds $\mathbf{3 0}$ or comparable fungicidal activity with compounds 30. In order to investigate whether the rule on the relationship between the activity and hydrogen-bonding has a general suitability to the macrocyclic compounds, further structural derivation on the compounds $\mathbf{4 0}$ was carried out: (a) A methyl group was introduced at $\mathrm{C} 15$ position and the 12-alkylsulfonamido-15-methyl-1,15- pentadecanlactones (41) were designed. (b) The lactone ring was replaced by lactam ring and the 12alkylsulfonamido-1,15-pentadecanlactams (43) were designed. (c) The sulfonamide group was transferred to the terminal of side chain and still kept a suitable distance between the two polarizable groups, and the $N$-(alkylsulfonamidoethyl)-1, 12-dodecanlactams (47) were designed. 


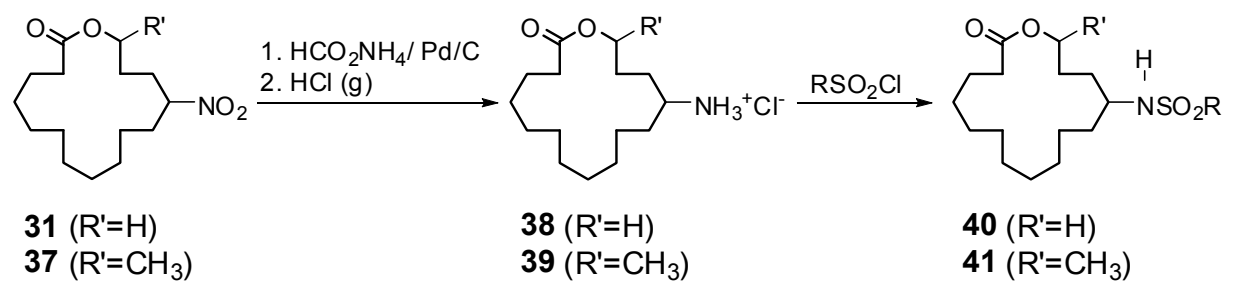

Scheme 9 . Synthetic route of macrolactones with a sulfonamide side chain (40 and 41)

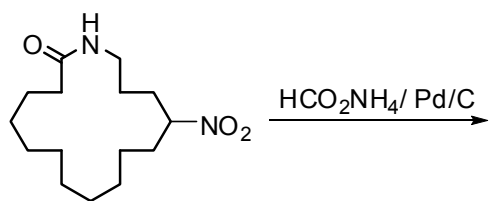

27<smiles>NCCCCCCCCCCCCCCCCCC(N)CCN</smiles>

42

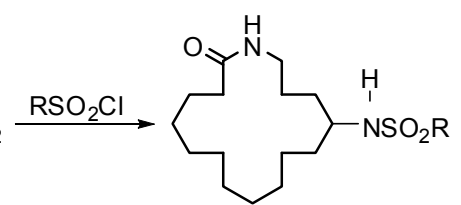

43

Scheme 10. Synthetic route of macrolactams with a sulfonamide side chain (43)
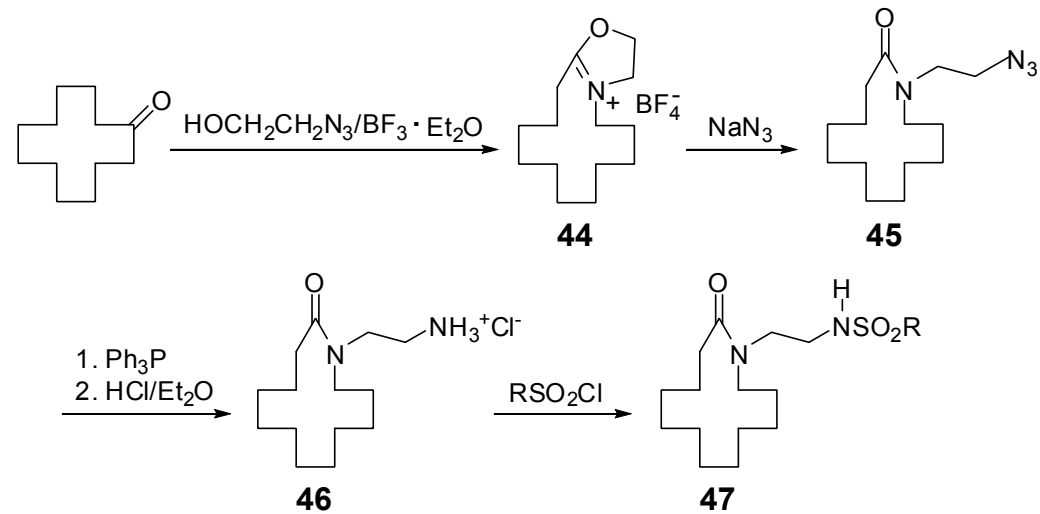

Scheme 11. Synthetic route of macrolactams with a sulfonamidoethyl side chain (47)

Compounds $\mathbf{4 0}$ and $\mathbf{4 1}$ were synthesized from intermediates $\mathbf{3 1}$ and $\mathbf{3 7}$ respectively by transfer hydrogenation using ammonium formate and palladium on carbon followed by sulfonylation with alkylsulfonyl chloride (Scheme 9). The compound 37 could be synthesized from nitrocyclododecanone (18) according to the method of synthesizing compound 31 just using methyl vinyl ketone instead of acrolein. Compounds 43 were synthesized from intermediate 27 according to the method of synthesizing compounds 40 (Scheme 10). The synthetic route of compounds 47 is shown in Scheme 11. Schmidt reaction (Li, 2006) of cyclododecanone with 2-azidoethanol followed by treating with sodium azide (Gracias et al, 1996; Gracias et al, 1997) give N-(2-azidoethyl)dodecanlactam (45), which was reduced and sulfonylated to afford compounds 47 . 
As shown in Table 3, compounds 40, 41, 43 and 47 displayed fair to excellent fungicidal activity against $R$. solani and have a gradual increase of fungicidal activity in the order of 41, 43, 47, and 40. Compounds 40 displayed well to excellent activity except individual compound 40k. Among them, compounds $40 \mathrm{a}, 40 \mathrm{~b}$ and $40 \mathrm{c}$, the $\mathrm{EC}_{50}$ values of which were 2.4, 3.7 and $3.3 \mu \mathrm{g} / \mathrm{mL}$ respectively, displayed excellent fungicidal activity and were comparable with compounds 30.

\begin{tabular}{ccccccccc}
\hline $\mathrm{R}$ & $\begin{array}{c}\text { Compds } \\
\text { No. }\end{array}$ & $\begin{array}{c}\mathrm{EC}_{50} \\
(\mu \mathrm{g} / \mathrm{mL})\end{array}$ & $\begin{array}{c}\text { Compds } \\
\text { No. }\end{array}$ & $\begin{array}{c}\mathrm{EC}_{50} \\
(\mu \mathrm{g} / \mathrm{mL})\end{array}$ & $\begin{array}{c}\text { Compds } \\
\text { No. }\end{array}$ & $\begin{array}{c}\mathrm{EC}_{50} \\
(\mu \mathrm{g} / \mathrm{mL})\end{array}$ & $\begin{array}{c}\text { Compd } \\
\text { s No. }\end{array}$ & $\begin{array}{c}\mathrm{EC}_{50} \\
(\mu \mathrm{g} / \mathrm{mL})\end{array}$ \\
\hline $\mathrm{C}_{6} \mathrm{H}_{5}$ & $\mathbf{4 0 a}$ & 2.4 & $\mathbf{4 1 a}$ & 51.3 & $\mathbf{4 3 a}$ & 55.3 & $\mathbf{4 7 a}$ & 11.6 \\
$4-\mathrm{MeC}_{6} \mathrm{H}_{4}$ & $\mathbf{4 0 b}$ & 3.7 & $\mathbf{4 1 b}$ & 57.0 & $\mathbf{4 3 b}$ & 13.4 & $\mathbf{4 7 b}$ & 8.8 \\
$4-\mathrm{ClC}_{6} \mathrm{H}_{4}$ & $\mathbf{4 0 c}$ & 3.3 & $\mathbf{4 1 c}$ & 69.6 & $\mathbf{4 3 c}$ & 19.6 & $\mathbf{4 7}$ & 18.7 \\
$3-\mathrm{O}_{2} \mathrm{NC}_{6} \mathrm{H}_{4}$ & $\mathbf{4 0 d}$ & 18.7 & $\mathbf{4 1 d}$ & 86.0 & $\mathbf{4 3 d}$ & 27.6 & $\mathbf{4 7 d}$ & 10.7 \\
$2,5-\mathrm{Cl}_{2} \mathrm{C}_{6} \mathrm{H}_{3}$ & $\mathbf{4 0 e}$ & 28.4 & $\mathbf{4 1 e}$ & 30.0 & $\mathbf{4 3 e}$ & 30.4 & $\mathbf{4 7 e}$ & 5.3 \\
$4-\mathrm{FC}_{6} \mathrm{H}_{4}$ & $\mathbf{4 0 f}$ & 4.5 & $\mathbf{4 1 f}$ & 25.1 & $\mathbf{4 3 f}$ & 36.7 & & \\
$2-\mathrm{ClC}_{6} \mathrm{H}_{4}$ & $\mathbf{4 0 g}$ & 25.0 & $\mathbf{4 1 g}$ & 37.9 & $\mathbf{4 3 g}$ & 59.5 & & \\
$2-\mathrm{O}_{2} \mathrm{NC}_{6} \mathrm{H}_{4}$ & $\mathbf{4 0 h}$ & 22.3 & $\mathbf{4 1 h}$ & 93.3 & $\mathbf{4 3 h}$ & 21.5 & & \\
$2-\left(\mathrm{MeCO}_{2} \mathrm{C}_{6} \mathrm{H}_{4}\right.$ & $\mathbf{4 0 i}$ & 20.9 & $\mathbf{4 1 i}$ & 53.4 & $\mathbf{4 3 i}$ & 12.8 & & \\
$\mathrm{~S}_{1}$ & $\mathbf{4 0 j}$ & 5.1 & $\mathbf{4 1 j}$ & 20.3 & $\mathbf{4 3 j}$ & 18.3 & & \\
$\mathrm{C}_{6} \mathrm{H}_{5} \mathrm{CH}_{2}$ & $\mathbf{4 0 k}$ & 52.4 & $\mathbf{4 1 k}$ & 28.2 & $\mathbf{4 3 k}$ & 8.1 & & \\
$\mathrm{CH}_{3}$ & $\mathbf{4 0 1}$ & 12.2 & $\mathbf{4 1 1}$ & 56.4 & $\mathbf{4 3 1}$ & 45.1 & & \\
\hline
\end{tabular}

Table 3. Fungicidal activity of compounds $40,41,43$ and 47 against $R$. solani

As mentioned above the designed idea of compounds 40 was originated from compounds 30 . In view of the hydrogen-bonding acceptor and hydrogen-bonding donor, compounds 40 and 30 (Figure 2) have similar structural characteristics although compounds $\mathbf{4 0}$ are macrolactones with a sulfonamide side chain and compounds $\mathbf{3 0}$ are macrolactams with an oxime ether side chain. The results showed that the rule on the relationship between the fungicidal activity and hydrogen-bonding has a general suitability to the macrocyclic compounds. Compounds 47 have somewhat lower fungicidal activity against $R$. solani than that of compounds 40 . Although the former is 13-membered lactam derivatives and latter 16-membered lactone derivatives, they are similar in the chemical structure (active moiety is similar and all of lipophilic moiety are ten to eleven methylenes of large rings). The difference is that greater part of active moiety of compounds $\mathbf{4 7}$ is out of large ring as the skeleton of side chain which is flexible instead of rigid. The flexible characteristics of active moiety reduce the reactivity of molecule in combination with target enzyme. This may be the reason why the fungicidal activity of compounds 47 is somewhat lower than that of compounds 40 .

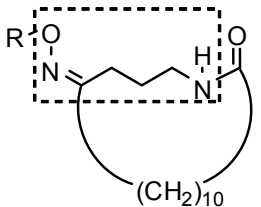

30

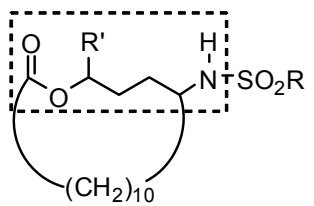

40,41

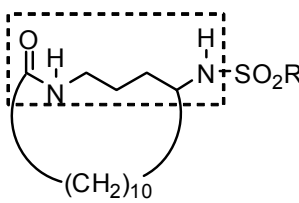

43

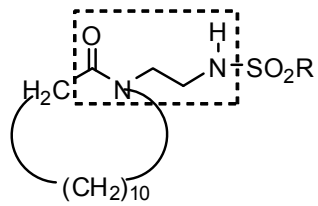

47

Fig. 3. Comparison of structures of compounds 30, 40, 41, 43 and 47. The structures of active moiety of compounds in the square frames are similar. 
Compounds 41 have a much lower fungicidal activity against $R$. solani (the $\mathrm{EC}_{50}$ values of all compounds 41 are larger than $20 \mu \mathrm{g} / \mathrm{mL}$ ) than that of compounds $\mathbf{4 0}$. However, their difference in chemical structure is only that there is a methyl group on the C15 for compounds 41 and none but hydrogen atom on the C15 for compounds $\mathbf{4 0}$, which indicated that methyl group plays an inhibitory role to the fungicidal activity. May be the existence of methyl group with a great volume between two polarizable groups will interferes in the interaction of pesticide molecules with target enzyme as shown in Figure 3. In the molecule of compounds 43 , carbonyl group of amide can play the role as hydrogen-bonding acceptor, therefore they have good fungicidal activity, but the active hydrogen on the nitrogen atom adjacent carbonyl would interfere in the interaction of pesticide molecules and target enzyme. This may be the reason why fungicidal activity of compounds $\mathbf{4 3}$ is lower than compounds 40.

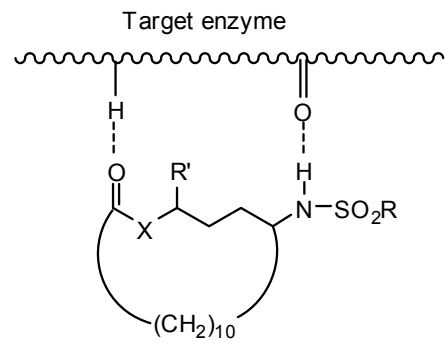

Fig. 4. Sketch map of the interaction of compounds 40, 41 and 43 with target enzyme: Pesticide molecules combine with target enzyme by hydrogen-bondings. Interaction of pesticide molecule with target enzyme is interfered by methyl group for compounds $\mathbf{4 1}$ ( $\mathrm{R}^{\prime}$ is methyl group and $\mathrm{X}$ is $\mathrm{O}$ ), and the interaction is interfered by active hydrogen on nitrogen atom for compounds $\mathbf{4 3}$ ( $\mathrm{X}$ is $\mathrm{NH}$ and $\mathrm{R}^{\prime}$ is $\left.\mathrm{H}\right)$.

\subsection{Synthesis and fungicidal activity of spiro-compounds containing macrolactam (macrolactone) and thiadiazoline rings $(50,51)$}

The result, from sections 3.1 and 3.2, indicated that it may be an effective approach to improve the bioactivity of cyclododecane derivatives to replace cyclododecane ring by macrolactam and macrolactone rings. Li et al (2010) designed and synthesized a series of spiro-compounds containing macrolactam and thiadiazoline rings (50), which retain a hydrogen-bonding donor (CO-NH) by replacing the cyclododecane ring of compounds $\mathbf{1 1}$ using macrolactam. For comparison, several spiro-compounds containing macrolactone and thiadiazoline rings (51) were also designed and synthesized.

Compounds 50 and 51 were synthesized by oxidative cyclisation of intermediates 48 and 49 , prepared by condensation reaction of 12-oxo-1,15-pentadecanlactam or 12-oxo-1,15pentadecanlactone and $\mathrm{N}$-substituted thiosemicarbazide, on treatment with manganese dioxide (Scheme 12)

Bioassay showed that compounds $\mathbf{5 0}$ have much better fungicidal activity than that of compounds 51 (Table 3). Compounds 50 have fair to excellent fungicidal activity against five fungi. However, compounds $\mathbf{5 1}$ have only poor fungicidal activity and the $\mathrm{EC}_{50}$ values of almost all compounds are greater than $30 \mu \mathrm{g} / \mathrm{mL}$. It is worth notice that compound $50 \mathrm{f}$ showed excellent fungicidal activity against $P$. oryzae, which is an important fungal pathogen causing serious damage to rice production in China. 


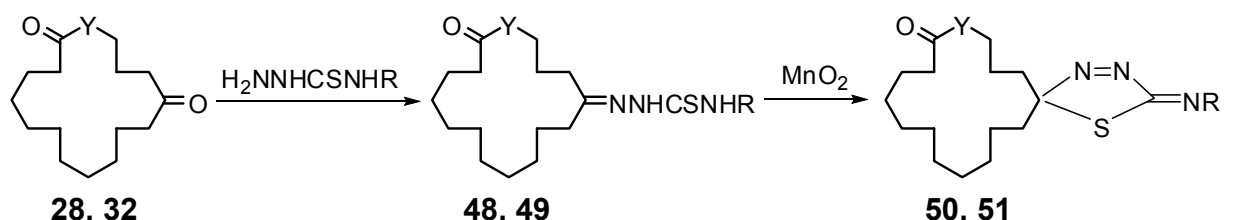

28,48 and $50, \mathrm{Y}=\mathrm{NH} ; 32,49$ and $51, \mathrm{Y}=\mathrm{O}$

Scheme 12. Synthetic route of spiro-compounds containing macrolactam (macrolactone) and thiadiazoline rings $(\mathbf{5 0}, \mathbf{5 1})$

X-ray diffraction analysis of two representative compounds (50f, $\mathrm{R}=\mathrm{p}-\mathrm{ClC}_{6} \mathrm{H}_{4} ; 51 \mathrm{c}, \mathrm{R}=\mathrm{o}-$ $\left.\mathrm{BrC}_{6} \mathrm{H}_{4}\right)$ showed that their large ring skeleton can be described as [333133] and [33343] conformation respectively (CCDC 739298; Li et al, 2007). The conformation of the large ring skeleton of two compounds is somewhat different from each other. However, they should be similar in the solution due to the dynamic equilibrium (Fig. 4). Namely, in view of the conformation, compounds $\mathbf{5 0}$ and $\mathbf{5 1}$ have similar structural characteristics (Fig. 5). However, there are a hydrogen-bonding donor (-CONH-) and a hydrogen-bonding acceptor $(\mathrm{N}=\mathrm{N}$ double bond of diazoline ring) on the large ring of compounds $\mathbf{5 0}$ and there are two hydrogen-bonding acceptor (-COO- and $\mathrm{N}=\mathrm{N}$ double bond of diazoline ring) without hydrogen-bonding donor on the large ring of compounds $\mathbf{5 1 .}$

\begin{tabular}{|c|c|c|c|c|c|c|}
\hline $\mathrm{R}$ & Compds No. & B. cinerea & S. sclerotiorum & R. solani & P. asparagi & P. oryzae \\
\hline $\mathrm{C}_{6} \mathrm{H}_{5}$ & $50 a$ & 5.01 & 9.92 & 42.08 & 14.18 & 41.51 \\
\hline $\mathrm{o}-\mathrm{CH}_{3} \mathrm{C}_{6} \mathrm{H}_{4}$ & $50 \mathrm{~b}$ & 4.21 & 375.43 & 124.79 & 73.79 & 78.43 \\
\hline $\mathrm{m}-\mathrm{CH}_{3} \mathrm{C}_{6} \mathrm{H}_{4}$ & $50 \mathrm{c}$ & 6.42 & 4.42 & 30.72 & 9.67 & 63.18 \\
\hline $\mathrm{p}-\mathrm{CH}_{3} \mathrm{C}_{6} \mathrm{H}_{4}$ & $50 d$ & 25.10 & 34.08 & 71.83 & 14.52 & 138.76 \\
\hline $\mathrm{o}-\mathrm{ClC}_{6} \mathrm{H}_{4}$ & $50 e$ & 14.89 & 241.56 & 31.80 & 24.48 & 41.51 \\
\hline $\mathrm{p}-\mathrm{ClC}_{6} \mathrm{H}_{4}$ & $50 f$ & 18.67 & 48.18 & 39.52 & 101.63 & 0.054 \\
\hline $\mathrm{o}-\mathrm{BrC}_{6} \mathrm{H}_{4}$ & $50 \mathrm{~g}$ & 19.86 & 533.29 & 56.13 & 60.32 & 57.59 \\
\hline $\mathrm{o}-\mathrm{CH}_{3} \mathrm{OC}_{6} \mathrm{H}_{4}$ & $50 \mathrm{~h}$ & 21.85 & 21.09 & 37.89 & 517.04 & 397.84 \\
\hline $\mathrm{p}-\mathrm{CH}_{3} \mathrm{OC}_{6} \mathrm{H}_{4}$ & $50 \mathrm{i}$ & 6.47 & 87.23 & 93.00 & 20.56 & 57.85 \\
\hline $2,3-\left(\mathrm{CH}_{3}\right)_{2} \mathrm{C}_{6} \mathrm{H}_{3}$ & $50 \mathrm{j}$ & 22.61 & 36.53 & 22.38 & 14.85 & 199.48 \\
\hline $2,4-\left(\mathrm{CH}_{3}\right)_{2} \mathrm{C}_{6} \mathrm{H}_{3}$ & $50 \mathrm{k}$ & 9.63 & 55.71 & 26.75 & 5.26 & 30.92 \\
\hline $2,5-\left(\mathrm{CH}_{3}\right)_{2} \mathrm{C}_{6} \mathrm{H}_{3}$ & 501 & 18.58 & 34.30 & 5.62 & 16.42 & 86.61 \\
\hline $3,4-\mathrm{Cl}_{2} \mathrm{C}_{6} \mathrm{H}_{3}$ & $50 \mathrm{~m}$ & 34.23 & 15.03 & 36.82 & 9.02 & 0.72 \\
\hline $2,5-\mathrm{Cl}_{2} \mathrm{C}_{6} \mathrm{H}_{3}$ & $50 n$ & 29.56 & 109.29 & 41.77 & 221.73 & 1.11 \\
\hline$\alpha$-naphythyl & $50 \mathrm{o}$ & 15.73 & 767.24 & 17.80 & 46.15 & 195.80 \\
\hline benzyl & $50 p$ & 14.44 & 8.32 & 23.49 & 21.33 & 116.85 \\
\hline $\mathrm{o}-\mathrm{ClC}_{6} \mathrm{H}_{4}$ & $51 a$ & 43.81 & 169.20 & 159.06 & 116.49 & 211.36 \\
\hline $\mathrm{p}-\mathrm{ClC}_{6} \mathrm{H}_{4}$ & $51 b$ & 49.95 & 59.91 & 126.32 & 42.48 & 338.37 \\
\hline $\mathrm{o}-\mathrm{BrC}_{6} \mathrm{H}_{4}$ & 51c & 36.42 & 204.57 & 207.69 & 53.55 & 246.10 \\
\hline $\mathrm{p}-\mathrm{BrC}_{6} \mathrm{H}_{4}$ & $51 d$ & 49.88 & 38.30 & 17.10 & 29.21 & 338.37 \\
\hline $2,5-\left(\mathrm{CH}_{3}\right)_{2} \mathrm{C}_{6} \mathrm{H}_{3}$ & $51 \mathrm{e}$ & 126.29 & 162.84 & 421.80 & 208.41 & 3123.76 \\
\hline
\end{tabular}

Table 4 . Fungicidal activity of compounds $\mathbf{5 0}$ and $\mathbf{5 1}$ against five fungi $\left(\mathrm{EC}_{50}, \mu \mathrm{g} / \mathrm{mL}\right)$ 

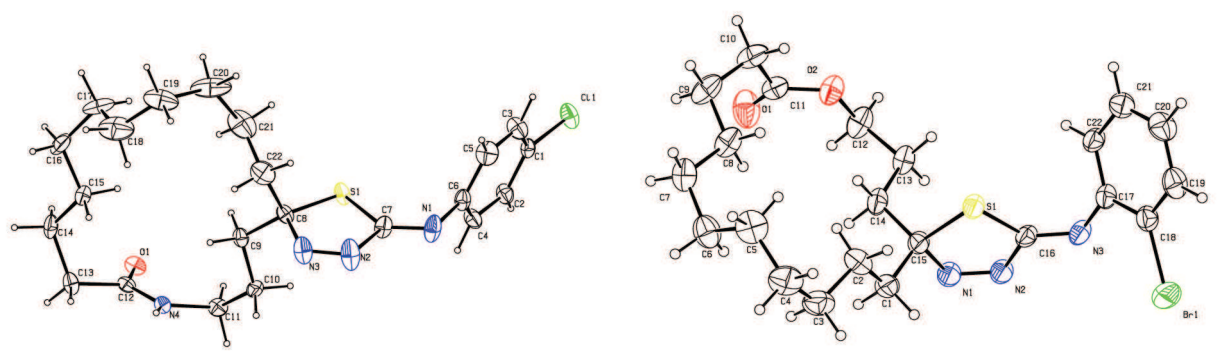

Fig. 5. The crystal structure of compound 50f (left) and 51c (right)
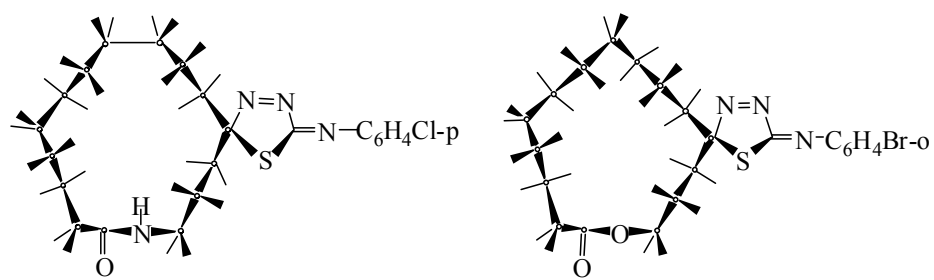

Fig. 6. The conformation of 50f (left) and 51c (right)

The results above showed that the presence of hydrogen-bonding donor to the fungicidal activity of macrocyclic compounds is very important and the rule on the relationship between the fungicidal activity and hydrogen-bonding has a general suitability to the macrocyclic compounds.

\subsection{Synthesis and fungicidal activity of 16-oxo-1-oxa-4-azoniacyclohexadecan-4-ium tetrafluoroborate}

Under the guidance of the rule on the relationship between the fungicidal activity and hydrogen-bonding, and following the principle of the simplicity of structure and the ease of synthesis, Dong et al (2008) designed and synthesized a novel azamacrolactone with a hydrogen donor $(\mathrm{NH})$ and a hydrogen acceptor $(\mathrm{C}=\mathrm{O})$ on the ring and two methylene groups between these two polarizable groups, 16-oxo-1-oxa-4-azoniacyclohexadecan-4-ium tetrafluoroborate (52). And for further verifying the role of hydrogen donor, several sulfonyl-derivatives (53) of $\mathbf{5 2}$ with only one polarizable group $(\mathrm{C}=\mathrm{O})$ were also synthesized. Compound 52 was synthesized by intramolecular Schmidt reaction (Li, 2006) of cyclododecanone with 2-azidoethanol. And sulfonylation of 52 afford compounds 53 (Scheme 13).

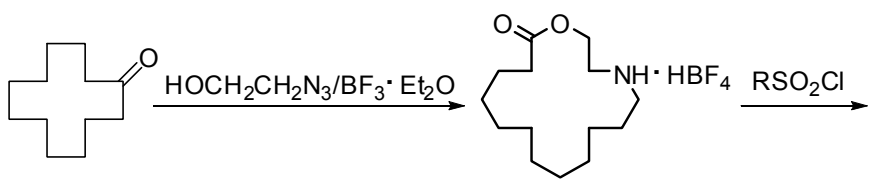

52

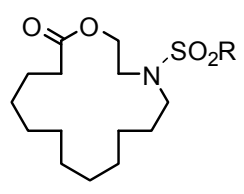

53

Scheme 13. Synthetic route of 16-oxo-1-oxa-4-azoniacyclohexadecan-4-ium tetrafluoroborate (52) and its sulfonyl derivatives (53) 
The fungicidal activity of compounds $\mathbf{5 2}$ and $\mathbf{5 3}$ against six fungus species in vitro was evaluated. The result showed that compound $\mathbf{5 2}$ has good fungicidal activity against these fungi, especially has excellent fungicidal activity against $R$. solani and is much better than compounds 53 which indicate that the presence of hydrogen-bonding donor to the fungicidal activity of macrocyclic compounds is indeed very important. In view of the ease of synthesis and the high fungicidal activity against $R$. solani, compound $\mathbf{5 2}$ will be expected to develop as a useful fungicide (see next section).

\begin{tabular}{|c|c|c|c|c|c|c|c|}
\hline \multirow[b]{2}{*}{$\mathrm{R}$} & \multirow[b]{2}{*}{$\begin{array}{c}\text { Compds } \\
\text { No. }\end{array}$} & \multicolumn{6}{|c|}{ Inhibition rate (\%) } \\
\hline & & $\begin{array}{c}\text { Rhizocto } \\
\text { nia solani } \\
\text { Kuhn }\end{array}$ & \begin{tabular}{|c|} 
Fulvia \\
fulva \\
(Cooke) \\
Ciferri
\end{tabular} & $\begin{array}{c}\text { Colletotrichum } \\
\text { orbiculare } \\
\text { (Berk. et } \\
\text { Mont.) Arx }\end{array}$ & $\begin{array}{c}\text { Verticilliu } \\
\text { m dahliae } \\
\text { Kleb. }\end{array}$ & $\begin{array}{c}\text { Sclerotinia } \\
\text { sclerotiorum } \\
\text { (Lib.) de } \\
\text { Bary }\end{array}$ & $\begin{array}{l}\text { Alterneria } \\
\text { kikuchiarna } \\
\text { Tanaka }\end{array}$ \\
\hline & 52 & 96.0 & 89.3 & 73.2 & 86.9 & 85.7 & 85.7 \\
\hline $\mathrm{C}_{6} \mathrm{H}_{5}$ & $53 a$ & 0.0 & 63.6 & 56.3 & 61.9 & 61.3 & 66.6 \\
\hline $\mathrm{p}-\mathrm{MeC}_{6} \mathrm{H}_{4}$ & $53 b$ & 0.0 & 50.1 & 46.4 & 50.7 & 39.5 & 52.5 \\
\hline $\mathrm{o}-\mathrm{Cl} \mathrm{C} \mathrm{H}_{4}$ & $53 c$ & 0.0 & 59.3 & 43.8 & 50.7 & 49.3 & 55.6 \\
\hline $\mathrm{p}-\mathrm{Cl} \mathrm{C} \mathrm{C}_{4}$ & $53 d$ & 0.0 & 45.0 & 0.0 & 44.5 & 39.5 & 55.6 \\
\hline $\mathrm{o}-\mathrm{O}_{2} \mathrm{NC}_{6} \mathrm{H}_{4}$ & $53 e$ & 0.0 & 45.0 & 43.8 & 34.6 & 36.0 & 52.5 \\
\hline $\mathrm{m}-\mathrm{O}_{2} \mathrm{NC}_{6} \mathrm{H}_{4}$ & $53 \mathrm{f}$ & 0.0 & 45.0 & 35.4 & 50.7 & 46.2 & 46.2 \\
\hline $\mathrm{p}-\mathrm{O}_{2} \mathrm{NC}_{6} \mathrm{H}_{4}$ & $53 \mathrm{~g}$ & 7.5 & 45.0 & 29.6 & 44.5 & 39.5 & 55.6 \\
\hline $\begin{array}{l}\mathrm{p}-(\mathrm{MeCO}- \\
\mathrm{NH}) \mathrm{C}_{6} \mathrm{H}_{4}\end{array}$ & $53 \mathrm{~h}$ & 27.1 & 39.8 & 32.5 & 41.3 & 32.4 & 32.4 \\
\hline
\end{tabular}

Table 5. Inhibition rate of the compounds 52 and 53 against six fungus species at $50 \mu \mathrm{g} / \mathrm{mL}$

\section{Development of the compounds with high fungicidal activity.}

In this section, the development of two compounds (30a and 52) with high fungicidal activity will be described.

\subsection{The development of compound 30a}

As described in section 3.1, 12-propoxyimino-1,15-pentadecanlactam (30a) (Fig. 5) exhibited a broad spectrum of fungicidal activity and especially excellent fungicidal activity against $A$. kikuchiana, $P$. physaleos, $R$. solani and B. cinerea in vitro. The $\mathrm{EC}_{50}$ values were $1.2,1.9,4.6$ and $8.6 \mu \mathrm{g} \mathrm{mL}^{-1}$ respectively.

The diseases caused by A. kikuchiana and P. physaleos are not common in China. However, $R$. solani is an important agricultural fungus which causes serious decrease in yield especially in major cotton-growing regions in China (Chen et al, 1998; Gong et al, 2004; Deng et al, 2006), and grey mould caused by $B$. cinerea has become one of the most widely distributed diseases in vegetable (cucumber, tomato, calabash, eggplant, onion etc) and fruit (apple, grape, strawberry etc) growing regions and seriously affects crop production in China (Zhang et al, 2005; Xu et al, 2005; Chen et al, 2006; Wang et al, 2006 ).

In this section, the development of compound 30a as a fungicide controlling cotton sheath blight ( $R$. solani) and vegetable (cucumber and tomato) grey mould (B. cinerea) through pot culture and field efficacy trials, its dynamic distribution in cotton plants, and its toxicology was described (Huang et al, 2009. Original code name of 30a was 7B3) 


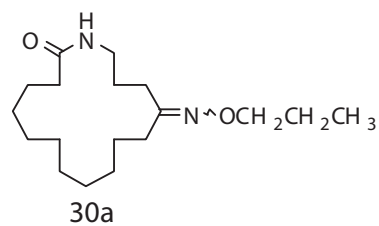

Fig. 7. Chemical structure of compound 30a

\subsubsection{Control effect of 30a against $R$. solani}

Compound 30a showed good control against $R$. solani on cucumber in the pot culture test (Table 6). The control effect of 30a reached $53.5 \%$ at a rate of $315 \mathrm{~g}$ ai ha-1, and was better than commercial fungicide thiram at a rate of $450 \mathrm{~g}$ ai ha-1 $(42.1 \%)$. The control effect of 30a reached $73.6 \%$ at a rate of $504 \mathrm{~g}$ ai ha-1 and is much better than thiram at a rate of $450 \mathrm{~g}$ ai ha-1.

\begin{tabular}{ccc}
\hline Treatment & Dosage, $\mathrm{g}$ ai ha-1 & Control effect $(\%)$ \\
\hline 30a 28\% WP & 168 & 39.0 \\
30a 28\% WP & 315 & 53.5 \\
30a 28\% WP & 504 & 73.6 \\
thiram 50\% WP & 450 & 42.1 \\
\hline
\end{tabular}

Table 6. Control effect of 30a against $R$. solani on cucumber in pot culture test (Soil drenching) In two-year two-place field efficacy trials, the control effect of 30a against $R$. solani on cotton reached $64 \sim 92 \%$ at a rate of $140 \mathrm{~g}$ ai ha-1 and was better than or comparable to commercial fungicide carbendazin at the same rate (Table 7).

\begin{tabular}{|c|c|c|c|c|}
\hline \multirow[b]{2}{*}{ Treatment } & \multicolumn{2}{|c|}{ Dosage } & \multicolumn{2}{|c|}{ Control effect (\%) } \\
\hline & $\begin{array}{c}\mathrm{g}, \mathrm{WP} / 1 \mathrm{~kg} \\
\text { seed }\end{array}$ & g, ai ha ${ }^{-1}$ & First year & Second year \\
\hline \multicolumn{5}{|c|}{ Site: Jinan, Shandong Province, China } \\
\hline \multirow{3}{*}{$\begin{array}{c}\text { 30a 25\% WP } \\
\text { 30a 25\% WP } \\
\text { carbendazin 50\% } \\
\text { WP }\end{array}$} & 4 & 93.3 & 88.9 & 65.3 \\
\hline & 6 & 140 & 91.5 & 74.7 \\
\hline & 3 & 140 & 82.1 & 58.3 \\
\hline \multicolumn{5}{|c|}{ Site: Yuncheng, Shanxi Province, China } \\
\hline \multirow{3}{*}{$\begin{array}{c}\text { 30a 25\% WP } \\
\text { 30a 25\% WP } \\
\text { carbendazin 50\% } \\
\text { WP }\end{array}$} & 4 & 93.3 & 69.2 & 61.9 \\
\hline & 6 & 140 & 72.7 & 64.4 \\
\hline & 3 & 140 & 73.1 & 63.3 \\
\hline
\end{tabular}

Table 7. Control effect of 30a against $R$. solani on cotton in field efficacy trials (Seed dressing)

\subsubsection{Control effect of $30 a$ against $B$. cinerea}

The control effect of $30 \mathbf{a}$ against $B$. cinerea on tomato in the pot culture test reached $85.8 \%$ at a rate of $315 \mathrm{~g}_{\text {ai ha- }}{ }^{-1}$ and $87.5 \%$ at a rate of $504 \mathrm{~g}$ ai ha-1 respectively, which is not as good as commercial fungicide huimeike [a mixed preparation of diethofencarb and chlorothalonil $(1: 1.8, w / w)]$, but is comparable to iprodione (Table 8). However, in a one-year one-place field efficacy trial (Table 9) 30a displayed excellent fungicidal activity against $B$. cinerea on 
cucumber. The control effect reached $95.1 \%$ at a rate of $450 \mathrm{~g}$ ai ha-1, and was comparable to huimeike (control effect was $96.1 \%$ at a rate of $504 \mathrm{~g}$ ai ha-1).

\begin{tabular}{ccc}
\hline Treatment & Dosage, g ai ha-1 & Control effect (\%) \\
\hline 30a 28\% WP & 168 & 80.7 \\
30a 28\% WP & 315 & 85.8 \\
30a 28\% WP & 504 & 87.5 \\
huimeike 28\% WP & 315 & 96.6 \\
Iprodione 50\% WP & 563 & 90.4 \\
\hline
\end{tabular}

Table 8. Control effect of $\mathbf{3 0 a}$ against $B$. cinerea on tomato in pot culture test (foliar spraying)

\begin{tabular}{ccc}
\hline Treatment & Dosage, $\mathrm{g}$, ai ha- ${ }^{-1}$ & Control effect (\%) \\
\hline 30a 25\% WP & 281 & 89.5 \\
30a 25\% WP & 450 & 95.1 \\
huimeike 28\% WP & 504 & 96.1 \\
\hline
\end{tabular}

Table 9. Field efficacy trials of 30a against $B$. cinerea on cucumber (Foliar spraying)

\subsubsection{Dynamic distribution of 30a in cotton plant}

The study showed that the concentration of 30a reached $54.44 \mu \mathrm{g} \mathrm{g}^{-1}$ in roots of cotton plants $4 \mathrm{~h}$ after treatment with $500 \mu \mathrm{g} \mathrm{mL}^{-1}$ of 30a (Table 10), which showed that 30a can penetrate through the epidermis of the root and be absorbed by cotton plants. The content of 30a in roots, stems and leaves all increased with extension of treatment time and the concentration of 30a reached 137.05, 5.12 and $2.53 \mu \mathrm{g} \mathrm{g}{ }^{-1}$ respectively, $48 \mathrm{~h}$ after treatment. However, the concentration of 30a in roots was almost 27 and 54 times of the concentration in stems and leaves respectively, which revealed that $30 \mathrm{a}$ has almost no acropetal translocation and systemic activity in cotton plant. The results provide a theoretical basis for an application method of $30 \mathrm{a}$ for soil treatment or seed coating treatment.

\begin{tabular}{cccc}
\hline \multirow{2}{*}{$\begin{array}{c}\text { Treatment } \\
\text { Time }(\mathrm{h})\end{array}$} & \multicolumn{3}{c}{ Content of 30a in the different parts of cotton plants $\left(\mu \mathrm{g} \mathrm{g}^{-1}\right)$} \\
\cline { 2 - 4 } & root & stem & leave \\
\hline 4 & $54.44 \pm 1.64$ & $0.19 \pm 12.30$ & $0.04 \pm 5.52$ \\
8 & $66.69 \pm 2.81$ & $0.87 \pm 1.91$ & $0.11 \pm 2.52$ \\
16 & $96.99 \pm 1.29$ & $2.71 \pm 2.08$ & $0.33 \pm 4.87$ \\
24 & $98.02 \pm 2.08$ & $4.27 \pm 2.93$ & $0.89 \pm 2.48$ \\
36 & $116.25 \pm 2.13$ & $8.95 \pm 6.84$ & $2.93 \pm 6.50$ \\
48 & $137.05 \pm 4.39$ & $5.12 \pm 3.84$ & $2.53 \pm 5.80$ \\
\hline
\end{tabular}

Table 10. Distribution of 30a in cotton plants when the chemical applied as root treatment 


\subsubsection{Toxicological test of $30 a$}

The results of toxicological tests indicated that 30a was a low toxicological compound ( $\mathrm{LD}_{50}>5000 \mathrm{mg} \mathrm{kg}^{-1}$ for acute oral and $\mathrm{LD}_{50}>2000 \mathrm{mg} \mathrm{kg}^{-1}$ for acute dermal) based on classification standard procedure of People's Republic of China (People's Republic of China, 1995). The teratogenesis, mutagenesis and carcinogenesis tests were negative; therefore 30a is safe for human being (Table 11).

\begin{tabular}{ll}
\hline Tested item & Results \\
\hline Acute oral (Rats) $\left(\mathrm{LD}_{50}, \mathrm{mg} / \mathrm{kg}^{-1}\right)$ & $>5000$ \\
Acute dermal (Rats) $\left(\mathrm{LD}_{50}, \mathrm{mg} / \mathrm{kg}^{-1}\right)$ & $>2000$ \\
Eye irritation (Rabbits) & slight irritation \\
Skin irritation (Rabbits) & not irritation \\
Mutagenesis & negative \\
Teratogenesis & negative \\
Carcinogenesis & negative \\
\hline
\end{tabular}

Table 11. Toxicological profile of 30a

\subsubsection{Conclusion}

30a has very weak systemic activity and is suitable for controlling cotton sheath blight with soil treatment or seed coating treatment. The field efficacy trials showed that the control effect of 30a against $R$. solani on cotton is better or comparable to carbendazin and against $B$. cinerea on cucumber is comparable to huimeike. Therefore, 30a may be expected to be further developed as a practical fungicide due to the high control effect, low toxicological properties and novel structure. However, the disadvantage is its long synthetic route from cyclododecanone (see Scheme 6).

\subsection{The development of compound 52}

As decribed in section 3.4, compound 52 (16-oxo-1-oxa-4-azoniacyclohexadecan-4-ium tetrafluoroborate) against six fungi ( $R$. solani and so on) has good fungicidal activity, especially has excellent fungicidal activity against $R$. solani, an important agricultural fungus in China.

In this section, the development of compound 52 as a fungicide controlling cotton sheath blight ( $R$. solani) through pot culture and field efficacy trials, and its toxicology was described (Dong et al, 2008. Original code name of $\mathbf{5 2}$ was 2a or D1)

\subsubsection{Control effect of 52 against $R$. solani on cotton}

The results of potted test (Table 12) and field efficacy trials showed that compound 52 against $R$. solani on cotton was more active than commercial fungicide carbendazim.

\begin{tabular}{|c|c|c|c|}
\hline \multirow{2}{*}{ Treatment } & \multicolumn{2}{|c|}{ Dosage } & \multirow{2}{*}{ Control effect (\%) } \\
\hline & $\mathrm{g}, \mathrm{WP} / 1 \mathrm{~kg}$ seed & g, ai ha-1 & \\
\hline $52,25 \% \mathrm{WP}$ & 2 & 47 & 81.8 \\
\hline $52,25 \% \mathrm{WP}$ & 3 & 70 & 87.2 \\
\hline Carbendazim, 50\% WP & 3 & 140 & 79.2 \\
\hline
\end{tabular}

Table 12. Control effect of $\mathbf{5 2}$ against $R$. solani on cotton in pot culture test (seed dressing) 


\begin{tabular}{ccccc}
\hline \multirow{2}{*}{ Treatment } & \multicolumn{2}{c}{ Dosage } & \multicolumn{2}{c}{ Control effect (\%) } \\
\cline { 2 - 5 } & $\begin{array}{c}\mathrm{g}, \mathrm{WP} / 1 \mathrm{~kg} \\
\text { seed }\end{array}$ & $\mathrm{g}$, ai ha-1 & First year & Second year \\
\hline $\mathbf{5 2}, \mathbf{2 5} \% \mathrm{WP}$ & 4 & 93.3 & 55.8 & 48.9 \\
$\mathbf{5 2}, 25 \% \mathrm{WP}$ & 6 & 140 & 61.9 & 63.6 \\
carbendazin 50\% WP & 3 & 140 & 49.6 & 53.4 \\
\hline
\end{tabular}

Table 13. Control effect of $\mathbf{5 2}$ against $R$. solani on cotton in field efficacy trials (seed dressing, site: Yuncheng, Shanxi Province, China)

\subsubsection{Toxicological test of $\mathbf{5 2}$}

The results of toxicological tests indicated that 52 was a low toxicological compound $\left(\mathrm{LD}_{50}>\right.$ $3160 \mathrm{mg} \mathrm{kg}^{-1}$ for acute oral and $\mathrm{LD}_{50}>2000 \mathrm{mg} \mathrm{kg}^{-1}$ for acute dermal)based on classification standard procedure of People's Republic of China (People's Republic of China, 1995). The mutagenesis, teratogenesis and carcinogenesis tests were negative; therefore $\mathbf{5 2}$ is safe for human being (Table 14).

\begin{tabular}{ll}
\hline Tested item & results \\
\hline Acute oral (Rats) $\left(\mathrm{LD}_{50}, \mathrm{mg} / \mathrm{kg}^{-1}\right)$ & $>3160$ (male) \\
& $>3160($ female) \\
& $>2000 \mathrm{mg} \mathrm{kg}^{-1}($ male $)$ \\
Acute dermal (Rats) $\left(\mathrm{LD}_{50}, \mathrm{mg} / \mathrm{kg}^{-1}\right)$ & $>2000 \mathrm{mg} \mathrm{kg}^{-1}($ female) \\
Eye irritation (Rabbits) & slight irritation \\
Skin irritation (Rabbits) & not irritation \\
Mutagenesis & negative \\
Teratogenesis* & negative \\
Carcinogenesis $^{*}$ & negative \\
\hline
\end{tabular}

Table 14. Toxicological profile of $\mathbf{5 2}$

*Unpublished results

\subsubsection{Conclusion}

The bioassay showed that compound $\mathbf{5 2}$ has excellent fungicidal activity against $R$. solani than commercial fungicide carbendazim. In addition, low toxicological property, short synthetic route and green synthetic technology with high atom economy (all of the atoms of raw materials including boron trifluoride were almost fully utilized except one nitrogen molecule and part of boron atoms lost, see section 3.4), indicated that compound $\mathbf{5 2}$ may be expected to further develop as a useful fungicide.

\section{The biochemical mode of action of compounds 30 a and 52 against $R$. solani}

In this section, effects of compounds 30a and 52 on ultrastructure of hyphae, cell membrane and respiration of mycelia cell suspension were described (Yan et al, 2010).

\subsection{Effect of 30a and 52 on morphology and ultrastructure transformation of $R$. solani} Mycelia of $R$. solani grew smoothly along the surface of culture media without 30a or 52, and the shape of the whole colony appeared to be radiated from its central point. The fringe of 
the colony was round and regular. However, the growth of mycelia was seriously depressed when it was cultured in the media with $50 \mu \mathrm{g} \mathrm{mL}-1$ 30a or 52. The fringe of the colony was concavo-convex, irregular, and is not as smooth and regular as that of control mycelia.

SEM images indicated that the mycelial grew well in control media (Mu et al, 2006; Butler and Bracker, 1970) and it was of low density, fresh and had a fine structure, and most of the mycelia ramification occurred in right angle (Fig. 8 A, D). However, there were similar morphology changes in mycelia of $R$. solani when mycelia were cultured in culture media with 30a or 52 of $50 \mu \mathrm{g} \mathrm{mL}^{-1}$. Mycelia grew abnormally with comparatively high density of colony, the ramification was not in right angle any more, the distance between ramifications decreased and some mycelia were entangled each other (Fig. 8 B, C). In the presence of 30a or 52, the surface of mycelia was rough (Fig. 8 B, E ) and mycelia were irregularly ramified and formed irregular ramification or abnormal configuration producing a "beaded" morphology with some parts of mycelia contracted and some parts swelled (Fig. 8 C).
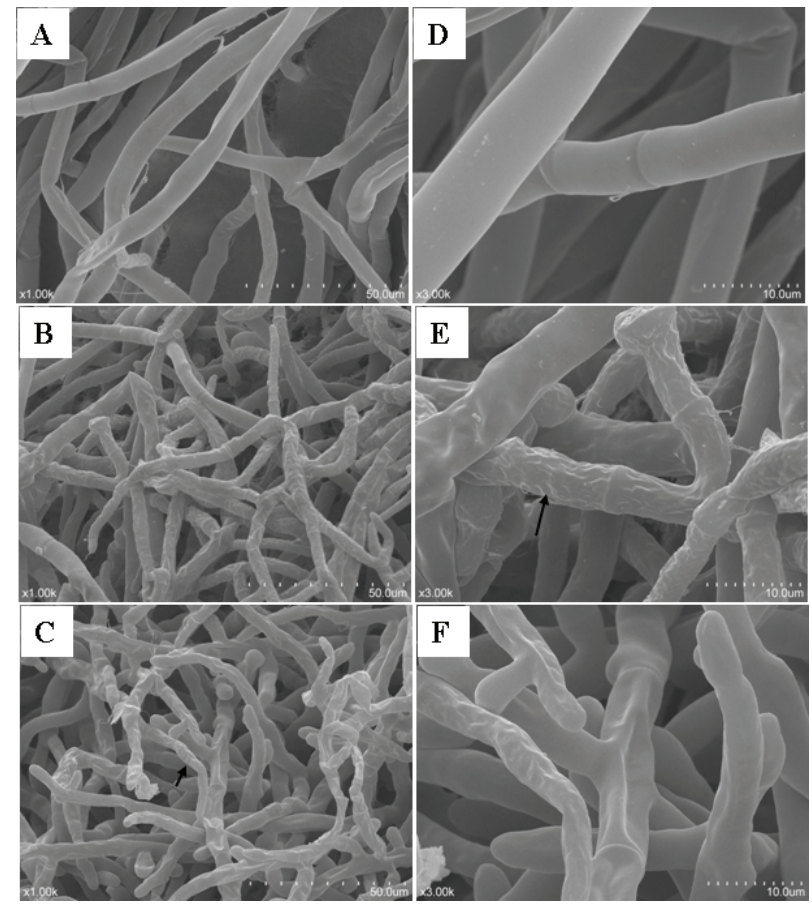

Fig. 8. Scanning electron micrographs of the hyphae from the colony of $R$. solani (A, D) 1000 (A) and 3000 (D) sections of $R$. solani hyphae grown on PDA medium in the absence of 30a or 52 (control) (the mycelium was low density, fresh and had a fine structure); (B, E) 1000 (B) and 3000 (E) sections of $R$. solani hyphae grown on PDA medium containing $50 \mu \mathrm{g} \mathrm{mL}^{-1} \mathbf{3 0 a}$ (the mycelium was comparatively high density of colony and the surface of mycelium was rough (arrowhead)); (C, F) 1000 (C) and 3000 (F) sections of $R$. solani hyphae grown on PDA medium containing $50 \mu \mathrm{g} \mathrm{mL}^{-1} \mathbf{5 2}$ (the amount of ramification increased and formed irregular ramification or abnormal configuration ("beaded" morphology) on the mycelium tip (arrowhead)). Bars: (A, B, C) $50.0 \mu \mathrm{m}$; (D, E, F) $10.0 \mu \mathrm{m}$ 
R. solani mycelial tips $(5 \mathrm{~mm})$ from the margin of actively growing colony on PDA medium were examined by TEM (Fig. 9). The cell walls and septa of the hyphae from the untreated control were uniform (Fig. 9 B, C). There were abundant organelles in cytoplasm such as vacuole $(\mathrm{V})$, mitochondria $(\mathrm{M})$ and lipid body (L) (Fig. 9 A). The dolipore septa and septal pore caps (SPCs) were obviously visible in control mycelia (Fig. 9 D). Following fungicides treatment, different ultrastructural modifications occurred in the hyphae (Fig. 9 G, $\mathbf{H}$ ultrastructure treated with 30a; Fig. 9 E, F, I, J ultrastructure treated with 52). The cell walls of the hyphae became considerably thicker following exposure to either 30a or 52 (Fig. 9 F, G). The walls of the septa were also abnormally thickened (Fig. 9 I).

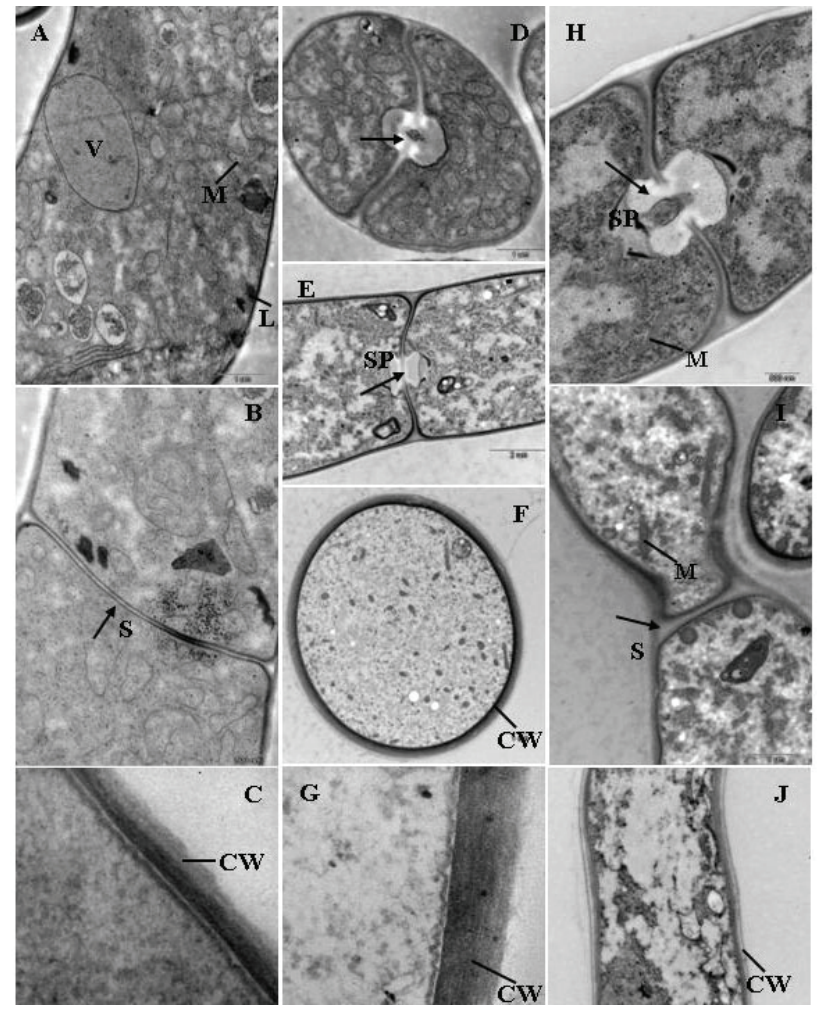

Fig. 9. Transmission electron micrographs of $R$. solani hyphae: (A, B, C, D) TEM of the hyphae of $R$. solani in the untreated control ((A) longitudinal of control hyphae; many organelles were observed such as vacuole (V), mitochondria (M) and lipid body (L); (B) uniform spectra (S) of control hyphae; (C) cell wall of control hyphae; (D) transverse of control hyphae and septal pore caps was visible); (E, F, I, J) TEM of the hyphae of $R$. solani treated with $50 \mu \mathrm{g} \mathrm{mL}^{-1} \mathbf{5 2}$ ((E) longitudinal of 52-treated hyphae (the septal pore caps disappeared); (F) transverse of 52treated hyphae (cell wall thickening); (I) longitudinal of 52-treated hyphae (septum of hyphae thickening); (J) longitudinal of 52-treated hyphae (cell wall thickening)); (G,H) TEM of the hyphae of $R$. solani treated with $50 \mu \mathrm{g} \mathrm{mL}-130 \mathrm{a}((\mathrm{G})$ cell wall thickening of 30a-treated hyphae; $(\mathrm{H})$ longitudinal of 30a-treated hyphae (the septal pore caps were almost unaffected)). Bars: (A, D, E, F, I, J) $1.0 \mu \mathrm{m} ;(\mathrm{B}, \mathrm{H}) 500 \mathrm{~nm}$; (C, G) $100 \mathrm{~nm}$. 
Under the treatment of $\mathbf{3 0 a}$ and $\mathbf{5 2}$, the organelles became disorganized and decreased in the hyphae cytoplasm (Fig. 9 F, G). Another striking characteristics was the disappearance of septal pore caps of 52-treated hyphae (Fig. 9 E), while the septal pore caps was almost not affected in 30a-treated hyphae (Fig. 9 H).

SEM and TEM observations revealed that growth inhibition of $R$. solani as a response to 30a and 52 was accompanied with marked morphological and cytological changes, including irregular ramification and a "beaded" morphology, excessive branching, irregular thickening of hyphae cell walls and necrosis or degeneration of hyphae cytoplasm. These changes were very similar to those occurring in some other fungi treated with chitosan and antibiotics, which inhibited fungi cell wall (Vesentini et al, 2007; Debono \& Gordee, 1994). The cell wall of fungi is a sturdy structure providing physical protection and osmotic support, which is considered as that complex of macromolecules with chitin, glucan and mannose interconnected by covalent bonds. Hyphae growth, branching, cell fusion and other morphogenetic events all depended on a balance between decomposition and extension of the hyphae wall, as well as on synthesis and incorporation of new wall material (Wessels, 1993; Kang et al, 2001). In the present study, the hyphae walls of $R$. solani were thickened irregularly and the excessive branching of the hyphae, which were very similar to the phenomena induced by EBI (ergosterol biosynthesis inhibitor) fungicides (Kang et al, 2001) although there are great differences in chemical structure between 30a or 52 and EBI fungicides. So it was also assumed that the thickness of cell wall and excessive branching might result from the changes of the activity of enzymes involved in wall synthesis. However, another phenomenon observed in TEM study was the increasing of thickness of septa and disappearance of septal pore caps of $\mathbf{5 2}$ treated hyphae. More studies should be done to interpret whether the phenomenon was in relation to cell wall associated enzymes.

\subsection{The effect of compounds 30 a and 52 on cell membrane of $R$. solani}

The effect of 30a and 52 on cell membrane was examined by measuring electrical conductivity of mycelia suspension. The conductivity of mycelia suspension treated with 30a, 52 and triadimefon all increased extremely comparing with the conductivity of control mycelia along with all the time of treatment. 52 induced more significant electrolyte leakage from hyphae than $\mathbf{3 0 a}$, and similar change with triadimefon. Thus it was proposed that $\mathbf{3 0 a}$ and 52 were all related to the impairment of cell membrane.

Electrolyte leakage was used as an indicator of cell membrane permeability of hyphae exposed to various fungicides. The alteration of conductivity induced by $30 \mathrm{a}$ and $\mathbf{5 2}$ resembled with the alteration caused by triadimefon, one of a class of azole compounds which can inhibit ergosterol biosynthesis and damage the permeability of cell membrane (Yoshida et al, 1990). These results indicated that both 30a and 52 caused damage to mycelia cell membrane system, induced electrolyte leakage from the cell, and as a result, the conductivity of solution was increased. Moreover, the presumption can also interpret the morphological and cytological alterations of the hyphae. Sterols are required for growth and reproduction of eukaryotic organisms and serve as architectural components of membranes. Thus, the thickening of hyphae walls was most likely to be associated with biochemical changes in the plasmalemma induced by $30 \mathrm{a}$ and $\mathbf{5 2}$. In addition, the phenomenon which 52 induced more significant grade in the morphological and cytological alterations and conductivity alteration than 30a probably can be explained by the difference of solubility between 52 and $\mathbf{3 0 a}$, because 52 was a tetrafluoroborate possessing better solubility in water than 30a. 


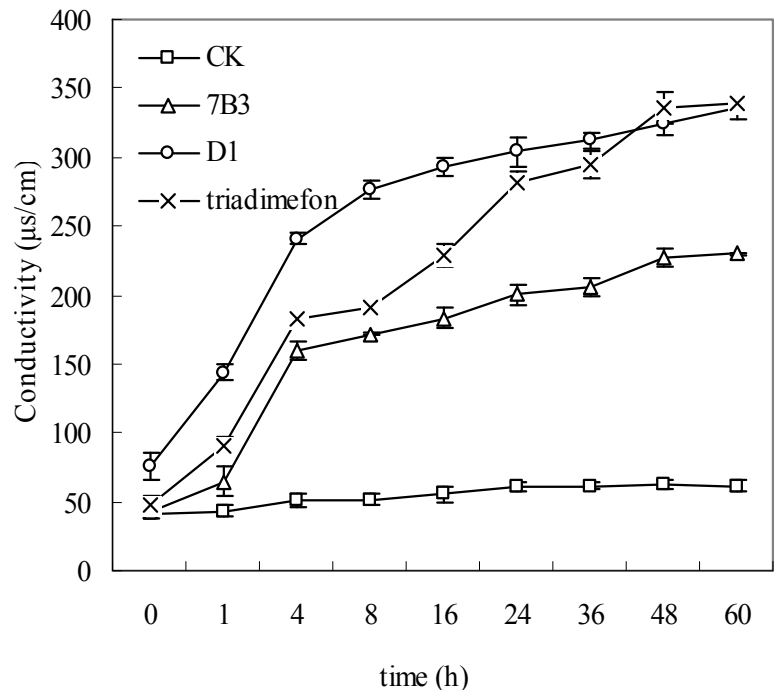

Fig. 10. Electrolyate leakage from $R$. solani suspensions during different time exposure to different fungicides. CK $(\square), 30 a(\Delta), 52(\circ)$, triadimefon $(\times)$. The conductivity of the solutions was measured using DDS-11C model conductivity detector at different treatment time after the addition of $1 \mathrm{~g}$ fresh mycelia into $50 \mu \mathrm{g} \mathrm{mL}^{-1}$ 30a, 52 and triadimefon solution, respectively.

\subsection{Effect on respiration of intact mycelia}

As shown in Table 15, both 30a and 52 almost did not affect oxygen consumption of intact mycelia while azoxystrobin, a respiration inhibitor, exhibited the strong effect on oxygen consumption of intact mycelia. These results proved that either 30a or 52 was not a respiration inhibitor and indicated that they did not disturb the energy generation system of R. solani.

\begin{tabular}{ccccc}
\hline Inhibitor & $\begin{array}{c}\text { Concentration } \\
\left(\mu \mathrm{g} \mathrm{mL} \mathrm{mL}^{-1}\right)\end{array}$ & $\begin{array}{c}\mathrm{R}_{0} \\
\left(\mu \mathrm{mol} \mathrm{\textrm {O } _ { 2 }} \mathrm{g}^{-1}\right. \\
\left.\mathrm{min}^{-1}\right)\end{array}$ & $\begin{array}{c}\mathrm{R}_{1} \\
\left(\mu \mathrm{mol} \mathrm{\textrm {O } _ { 2 }} \mathrm{g}^{-1}\right. \\
\left.\mathrm{min}^{-1}\right)\end{array}$ & $\begin{array}{c}\text { Inhibition rate } \\
(\%)\end{array}$ \\
\hline $\mathbf{3 0 a}$ & 10 & $27.03 \pm 1.39$ & $26.30 \pm 0.85$ & $3.39 \pm 0.62$ \\
& 100 & $27.03 \pm 1.39$ & $23.95 \pm 7.49$ & $12.05 \pm 5.50$ \\
52 & 10 & $27.03 \pm 1.39$ & $26.77 \pm 1.39$ & $1.67 \pm 1.02$ \\
azoxystrobin & 100 & $27.03 \pm 1.39$ & $26.41 \pm 2.45$ & $3.00 \pm 1.80$ \\
\hline
\end{tabular}

Table 15. Respiratory inhibition of intact mycelia of $R$. solani by $\mathbf{3 0 a}$ and $\mathbf{5 2}$

\subsection{Conclusion}

Both 30a and 52 caused marked changes of hyphae with a "beaded" morphology, excessive branching, irregular thickening of hyphae cell walls and necrosis or degeneration of hyphae 
cytoplasm and electrolyte leakage of membrane. In addition, neither 30a nor 52 affected the respiration of mycelia. These results suggested that 30a and 52 had the similar mode of action against $R$. solani relating to the impairment of biosynthesis of cell wall or membrane,

\section{References}

Attygalle, A. B.; McCormick, K. D.; Blankespoor, C. L.; Eisner, T. \& Meinwald, J. (1993). Azamacrolides: A family of alkaloids from the pupal defensive secretion of a ladybird beetle (Epilachna varivestis). Proc. Natl. Acad. USA, 90, 5204-5208.

Butler, E. E. \& Bracker, C. E (1970). Morphology and cytology of R. solani. Univ. of California University of California: Berkeley, C A, pp 32-50.

CCDC 739298 contains supplementary crystallographic data for compound 50f. These data can be obtained free of charge from the CCDC, 12 Union Road, Cambridge CB2 1EZ,U.K. Telephone (44) 01223 762910; e-mail deposit@ccdc.cam.ac.uk

Chen, L; Wang, D. Q. \& Jin, S. H. (2002). Synthesis and fungicidal activity of 2-(1,11undecylidene)-5-substituted imino- $\Delta^{3}-1,3,4$-thiadiazolines. Chin. J. Appl. Chem., 19(3), 212-215.

Chen, S. Q.; Wu, B.; Qin,Z.; Lin, G. Z.; Den, L. \& Den, X. M. (1998). A Study on the Anostomasis Group of Rhizoctonia Solani Kühn in Sichuan Province. Southwest China J. Agric Sci., 12 (1), 56-60.

Chen, Y. F.; Wen, J. Z. \& Li, L. J. (2006). Research advance of Grape Mould. J. Northeast Agric. Univ., 37(5), 693-699.

Crouse, G. D.; Sparks, T. C.; Schoonover, J.; Gifford, J.; Dripps, J.; Bruce, T.; Larson, L. L.; Garlich, J.; Hatton, C.; Hill, R. L.; Worden, T. V. \& Martynow, J. (2001). Recent advances in the chemistry of spinosyns. Pest Manag. Sci., 57, 177-185.

Davies, H. G. \& Green, R. H. (1991). Avermectins and Milbemycins Part I. Chem. Soc. Rev., 20, 211-269

Debono, M. \& Gordee, R. S. (1994). Antibiotics that Inhibit Fungal Cell Wall Development. Annu.Rev. Microbiol., 48 (1), 471-497.

Dehne, H. W. in Modern Fungicides and Antifungal Compounds V, 15th International Reinhardsbrum Symposium edited by Dehne, H. W.; Deising, H. B.; Gisi, U.; Kuck, K. H.; Russell, P. E. and Lyr, H. 2007, Page XXIII, Friedrichroda, Germany

Deng, Z. S.; Zhang, B. C.; Sun, Z. H. \& Zhou, M. L. (2006). Study on the Anastomotic Group of Rhizoctonia Solani isolated from Cotton Fields and Their Pathogenicity in Northern Xinjiang. Plant Protection, 32 (4), 36-39.

Dong, Y. H.; Liang, X. M.; Yuan, H. Z; Qi, S. H.; Chen, F. H. \& Wang, D. Q. (2008). Potential Green Fungicide: 16-oxo-1-oxa-4-azoniacyclohexa-decan-4-ium tetrafluoroborate. Green Chem., 10, 990-994.

Fang, X. Q.; Liang, X. M.; Yu, C. X.; Wu, J. P. \& Wang, D. Q. (2007). Study on synthesis of anitrocyclododecanone. Chem. World, 48(2), 110-113.

Fisher, M. H. (1990). Recent advances in avermectin research. Pure E Appl. Chem., 62(7), 1231-1240.

Gong, S. J.; Li, G. Y. \& Ling, G. C. (2004). Detection of Resistance of Cotton Varieties to Rhizoctonia Solani. J. Shihezi Uni. (Natural Sci.), 22 (sup.), 55-56.

Gracias, V.; Milligan, G. L. \& Aube, J. (1996). Synthesis of functionalized N-alkyl heterocycles from ketone by a sequential ring expansion/nucleophilic addition process. J. Org. Chem., 61 (1), 10-11. 
Gracias, V.; Frank, K. E.; Milligan, G. L. \& Aube, J. (1997). Ring expansion by in situ tethering of hydroxyl azides to ketone: The Boyer Reaction. Tetrahedron, 53 (48), 16241-16252.

Hou, X. T.; Chen, C.; Liang, X. M.; Wu, X. M.; Wu, J. P.; Jin, S. H. \& Wang D. Q. (1999). Synthesis and herbicidal activities of (E)-O-aroyl-a-Oxocyclododecanone Oximes. Chin. J. Pestic. Sci., 1(1), 40-44.

Hou, C. J.; Liang, X. M.; Wu J. P.; Tian, M. L. \& Wang, D. Q. (2006). A new synthesis of 12oxo-1,15-pentadecanlactam. Chin. J. Org. Chem., 26(11), 1597-1599.

Huang, J. X.; Liang, X. M. \& Wang, D. Q. (2004). A new route to 12-oxo-1,15pentadecanlactam. Chin. Chem. Lett., 15(2), 169-170.

Huang, J. X.; Jia, Y. M.; Liang, X. M.; Zhu, W. J.; Zhang, J. J.; Dong, Y. H.; Yuan, H. Z.; Qi, S. H.; Wu, J. P.; Chen, F. H. \& Wang, D. Q. (2007). Synthesis and Fungicidal Activity of Macrolactams and Macrolactones with an Oxime Ether Side Chain. J. Agric. Food Chem., 55, 10857-10863.

Huang, J. X.; Liang, X. M.; Zhang, J. J.; Yan, X. J.; Dong, Y. H.; Li, C. S.; Zhang, L. P.; Xu, Z. T.; Li, L.; Yuan, H. Z.; Qi, S. H.; Chen, F. H. \& Wang, D. Q. (2009). Fungicidal Activity of 12-Propoxyimino-1,15-pentadecanlactam on selected Crops. Crop Protection, 28, 947-951.

Jakobi, M.; Winkelmann, G.; Kaiser, D.; Kempter, C.; Jung, G.; Berg, G. \& Bahl, H. (1996). Maltophilin: A new antifungal compound produced by Stenotrophomonas maltophilia R3089. J. Antibiotics, 49(11), 1101-1104.

Jia, Y. M.; Liang, X. M.; Chang, L. \& Wang D. Q. (2007). Synthesis of 12-oxo-1,14tetradecanlactam. Synthesis, (5), 744-748.

Kang, Z.; Huang, L.; Krieg, U.; Mauler-Machnik, A. \& Buchenauer, H. (2001). Effects of tebuconazole on morphology, structure, cell wall components and trichothecene production of Fusarium culmorum in vitro. Pest Manag. Sci., 57 (6), 491-500.

Kastanise, M. A. \& Chrysayi-Tokousbalides, M. (2000). Herbicidal potential of pyrenophorol isolated from a Drechslera avenae pathotype. Pest Manag. Sci., 56, 227-232.

Li, X. H.; Yang, X. L.; Ling, Y.; Fan, Z. J.; Liang, X. M.; Wang, D. Q.; Chen, F. H. \& Li, Z. M. (2005). The Synthesis and Fungicidal Activity of Novel 2 Oxocycloalkylsulfonylureas. J. Agric. Food Chem., 53, 22022206.

Li, J. J. Name Reaction, 3 rd. expanded ed. Springer-Verlag, Berlin Heidelberg, 2006, P563564.

Li, M. L.; Liang, X. M.; Qin, Z. H.; \& Wang, D. Q. (2006). Synthesis and fungicidal activities of (E)-a-Oxocyclo- dodecanone Oxime Ethers. Chin. J. Pestic. Sci., 8(3), $209 \sim 213$.

Li, J. J.; Jin, S. H.; Liang, X. M.; Yuan, D. K \& Wang, D. Q. (2007) 1-Thia-2bromophenylimino- 3,4-diaza-9-oxa-10-oxospiro[4.15]-3-eicosylene, Acta Cryst. Section E, 63(4), o1940 o1941.

Li, J. J.; Liang, X. M.; Jin, S. H.; Zhang, J. J.; Yuan, H. Z.; Qi, S. H.; Chen, F. H \& wang, D, Q. (2010). Synthesis, Fungicidal Activity and Structure-activity Relationship of Spirocompounds Containing Macrolactam (Macrolactone) and Thiadiazoline Rings. J. Agric. Food Chem., 58, 2659-2663.

Mu, K. G.; Zhao, X. Q.; Hu, L.; Zhang, F. S.; Zhang, W. J. \& Cui, J. Y. (2006). Toxicity of Lanthanum to Pathogenic Fungi and Its Morphological Characteristics. Journal of Rare Earths, 24, 607-612. 
Pan, C. P. and Wang, D. Q. (1993). Study on synthesis of a-nitrocyclododecanone, Chem. Reagents, 15(6), 367-368.

Song, Y. N.; Wang, D. Q. \& Wang, M. A. (2005). Synthesis of a-methylthiocyclododecanone oxime ether and fungicidal activity. Chin. J. Pestic. Sci., 7(3), 210-214.

Sparks, T. C.; Thompson, G. D.; Kirst, H. A.; Hertlein, M. B.; Larson, L. L.; Worden, T. V. \& Thibault, S. T. (1998). Biological activity of the spinosyns, new fermentation derived insect control agents, on tobacco budworm (Lepidoptera: Noctuidae) larvae. J. Econ. Entomol., 91(6), 1277-1283.

Standardization Administration of the People's Republic of China. Standard No. GB 15670, 1995: Toxicological test methods of pesticides for registration.

Vesentini, D.; Steward, D.; Singh, A. P.; Ball, R.; Daniel, G. \& Franich, R. (2007). Chitosanmediated changes in cell wall composition, morphology and ultrastructure in two wood-inhabiting fungi. Mycol. Res., 111 (8), 875-890.

Wang, X. P. \& Wang, D. Q. (1997). Synthesis and antifungal activity of N-substituted- $\alpha-$ oxocyclododecyl- sulphonamides. Chem. J. Chin. Univ., 18 (6), 889-893.

Wang, M. A.; Ma, Z. C.; Jin, S. H. \& Wang, D. Q. (2002). Conformation of 2-(1,11undecylidene)-5-substituted imino- $\Delta^{3}-1,3,4$-thiadiazoline, Chin. J. Org. Chem., 22(8), 594-598.

Wang, S.; Fu, J. F. \& Yan, X. R. (2006). Fungitoxity of Seven Medicinal Plant Extracts on Botrytis cinerea. Plant Protection, 32(2), 59-60.

Weber, H.; Ring, W.; Hochmuth, U. \& Franke, W. (1965). Mechanism of formation of cis, trans, trans-cyclododeca- 1,5,9-triene by titanium-containing Ziegler catalysts. Liebigs Ann.Chem., 681, 10-20.

Wessels, J. G. H. (1993). Tansley Review No. 45 Wall growth, protein excretion and morphogenesis in fungi. New Phytol., 123 (3), 397-413.

Wilke, G. \& Muller, H. (1958). 1,5,9-Cyclododecatrienes. DE 1043329.

Xie, G. R.; Wang, X. P.; Wang, D. Q.; Su, Y. \& Zhou, J. J. (1999). QSAR study of $\alpha-$ oxocyclododecylsulphonamides by CoMFA. Chin. J. Pestic. Sci., 1 (2), 17-24.

Xu, Z. Y.; Guan, X. Y.; Shi, C. X.; Guan, C. M. (2005). Occurrence Regularity and Controlling Technique of Vegetable Grey mould in Protected Ground. Chinese Agric. Sci. Bull., 21(8), 339-342.

Yan, X. J.; Liang, X. M.; Jin, S. H.; Lv, J. P.; Yu, C. X.; Qi, W. Y.; Li, B. J.;Yuan, H. Z.; Qi, S. H.; Shi, Y. X.; Wu, J. P.; Chen, F. H. \& Wang D. Q. (2010). The primary Study of mode of action for macrocyclic fungicide candidates (7B3, D1) against Rhizoctonia solani. Kühn. J. Agric. Food Chem., 58, 2726-2729.

Yoshida, M.; Kawasaki, A.; Yukimoto, M. \& Nose, K. (1990). Detection of the effects of fungicides on the cell membrane by proton nuclear magnetic resonance spectroscopy. Pestic. Biochem. Phys., 38 (2), 172-177.

Zhang, Z. Y.; Jin, S. H.; Liang, X. M.; Wang, Z. Q. \& Wang, D. Q. (2001). Oxidative cyclisation of $\mathrm{N}$-substituted cyclododecanone thiosemicarbazones. Chin. J. Org. Chem., 21(3), 235-237.

Zhang, J. J.; Dong, Y. H.; Liang, X. M. \& Wang, D. Q. (2003). Synthesis and characterization of 12-acyloxyimino- 1,15-pentadecanolides. Chem. J. Chinese Universities, 24(9): 16041609. 
Zhang, Z.; Li, J. M.; Song, Y.; Yun, X. F.; Xu, H. J.; Zhou Y. J. (2005). An overview of the grey mold (Botrytis cinerea) and the control of it in tomato. J. Inner Mongolia Agric Univ. 26(2) 125-128.

Zhu, W. J.; Wu, P.; Liang, X. M.; Dong, Y. H.; Zhang, J. J.; Yuan, H. Z.; Qi, S. H.; Meng, X. Q.; Wu, J. P.; Chen, F. H. \& Wang, D. Q. (2008). Design, synthesis and fungicidal activity of macrolactones and macrolactams with a sulfonamide side chain. J. Agric. Food Chem., 56, 6547-6553. 


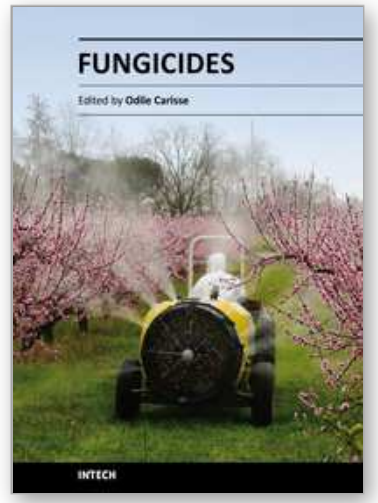

\author{
Fungicides \\ Edited by Odile Carisse
}

ISBN 978-953-307-266-1

Hard cover, 538 pages

Publisher InTech

Published online 14, December, 2010

Published in print edition December, 2010

Plant and plant products are affected by a large number of plant pathogens among which fungal pathogens. These diseases play a major role in the current deficit of food supply worldwide. Various control strategies were developed to reduce the negative effects of diseases on food, fiber, and forest crops products. For the past fifty years fungicides have played a major role in the increased productivity of several crops in most parts of the world. Although fungicide treatments are a key component of disease management, the emergence of resistance, their introduction into the environment and their toxic effect on human, animal, non-target microorganisms and beneficial organisms has become an important factor in limiting the durability of fungicide effectiveness and usefulness. This book contains 25 chapters on various aspects of fungicide science from efficacy to resistance, toxicology and development of new fungicides that provides a comprehensive and authoritative account for the role of fungicides in modern agriculture.

\title{
How to reference
}

In order to correctly reference this scholarly work, feel free to copy and paste the following:

Dao-Quan Wang (2010). Research and Development of Macrocyclic Compounds as Fungicides, Fungicides, Odile Carisse (Ed.), ISBN: 978-953-307-266-1, InTech, Available from:

http://www.intechopen.com/books/fungicides/research-and-development-of-macrocyclic-compounds-asfungicides

\section{INTECH}

open science | open minds

\section{InTech Europe}

University Campus STeP Ri

Slavka Krautzeka 83/A

51000 Rijeka, Croatia

Phone: +385 (51) 770447

Fax: +385 (51) 686166

www.intechopen.com

\section{InTech China}

Unit 405, Office Block, Hotel Equatorial Shanghai

No.65, Yan An Road (West), Shanghai, 200040, China 中国上海市延安西路65号上海国际贵都大饭店办公楼405单元

Phone: +86-21-62489820

Fax: $+86-21-62489821$ 
(C) 2010 The Author(s). Licensee IntechOpen. This chapter is distributed under the terms of the Creative Commons Attribution-NonCommercialShareAlike-3.0 License, which permits use, distribution and reproduction for non-commercial purposes, provided the original is properly cited and derivative works building on this content are distributed under the same license. 